ISSN (print) 0867-2008 / ISSN (online) 239 I-75 I 2

DOI: http://dx.doi.org/10.12775/OM.2018.004

pp. 93-125

\title{
Kristjan ToOmaspoeg*
}

Dipartimento di Storia, Società e Studi sull'Uomo

Università del Salento

Ex monastero degli Olivetani

viale San Nicola

I-73100 Lecce

Italy

kristjan.toomaspoeg@unisalento.it

\section{THE MILITARY ORDERS AND THE DIOCESAN BISHOPS: A PRAGMATIC RELATIONSHIP}

\section{KEYWORDS}

history; military orders; the Middle Ages; bishops; clergy; colonization; exemption; usurpations

\begin{abstract}
The relations of the Military Orders with the bishops are a fundamental topic of their history. A lecture of the primary sources and of the existing secondary literature points out a very intricate system of relations between the orders and the diocesan powers. There are cases of a friendly alliance and of an enthusiastic support and collaboration, as well those of a pacific but "cold" coexistence, followed by a long series of conflicting relationships, issues and clashes, sometimes accompanied by physical violence, usurpations and sentences of excommunication. At the same time, the relations undergo an evolution and in every diocese the friendship could be transformed in conflict or vice versa. The paper intends to offer very short reflections on this topic, taking under observation some specific cases as those of the Kingdoms of Sicily and Portugal, but supported by examples coming from several eastern and western regions. The aim is to proceed with an attempt of classification of the relations between the orders and the clergy and to follow their general evolution, filling a gap in the general history of the Military Orders. The paper is articulated in three parts dedicated respectively to "friendly" relations with bishops, to conflicts and to mutual agreements.
\end{abstract}

*ORCID: https://orcid.org/o000-000 I-5 I 79-904 I 
$\mathrm{I}$ n the afternoon of 22 April 1344, a group of Hospitallers and their friends and supporters burst into the palace of the archbishop of Messina, Raymond Pujol, to present an official protest before him. The latter refused to receive the Hospitallers and locked himself in his apartments. The brethren then began knocking on the door, exclaiming $O$ domine archiepiscope, permictatis nos intrare et audiatis appellacionem nostram. Finally, they charged a notary to read out a petition denouncing Pujol's intention to excommunicate the Hospitaller priory of Messina. As the priory had refused to pay him a tax (the Caritativum subsidium), the archbishop had forbidden the Hospitaller priests to administer the sacraments, had prohibited the use of the priory cemetery, and had revoked its right to hold the annual Corpus Christi procession. ${ }^{1}$ One month later, some of the laymen who had supported the Hospitallers in April besieged the archbishop's palace and Pujol, crucifix in hand, had to beg the attackers for mercy. ${ }^{2}$

The event is but one among many examples of clashes between the military orders and the diocesan bishops. Nevertheless, the orders largely owed their existence to initial support from the prelates. In fact, the primary sources and the existing secondary literature alike make it clear that there existed a very intricate system of relations between the orders and the secular clergy. There are cases of friendly alliances and of enthusiastic support and collaboration, as well as examples of an untroubled but nonetheless cold coexistence, followed by protracted conflicts, disagreements and clashes, sometimes accompanied by physical violence, usurpations, and sentences of excommunication and interdict. Relationships such as these were not still, and in every diocese friendship might turn into conflict and vice versa.

I The minute written by an anonymous notary and describing the events of April 22 was originally conserved in the city archives of Messina, where it was copied by an unknown hand in 1659 (this copy was added to the manuscript of the historian Antonino Amico containing many lost documents on the Hospitallers of Messina, today in Palermo, Biblioteca Comunale, Qq H i 2 , fol. $173-178$ ). The original was thereafter transported to Spain where it was recently found in the Archivo Ducal de Medinaceli, Adm., Archivio Histórico, legajo 98- I. The Palermo copy is catalogued in Carlo Marullo di Condojanni, La Sicilia ed il Sovrano Ordine Militare di Malta (Messina: Grafiche "La Sicilia", I953), I I3- I 4 no. 88, and Kristjan Toomaspoeg, Templari e Ospitalieri nella Sicilia Medievale (Taranto-Bari: Centro Studi Melitensi, 2003), I 95 no. I94, and edited by Luciana Petracca, Giovanniti e Templari in Sicilia, vol. II, Il ms. Qq HI 2 della Biblioteca Comunale di Palermo (Galatina: Congedo, 2006), 299-302 (Source edition). The original in Spain has been studied in Daniela Santoro, "L'arcivescovo e l'Ospedale. Raimondo de Puyolis contro i Gerosolimitani di Messina (1344)," in Istituzioni ecclesiastiche e potere regio nel Mediterraneo medievale. Scritti per Salvatore Fodale, ed. Patrizia Sardina, Daniela Santoro and Maria Antonietta Russo (Palermo: Associazione no profit Mediterranea, 2016), 75-89, a paper that unfortunately ignores the existence of previous studies and editions.

2 Santoro, "L'arcivescovo," 88-89. 
This topic has been examined in depth for some geographical areas and some military orders, namely the Hospitallers and the Templars in the Latin East ${ }^{3}$, in the Kingdom of Castile $e^{4}$, in southern and central Frances, in the Kingdom of England and in Ireland ${ }^{6}$. The same is true of the Iberian orders of Alcántara, Calatrava and Santiago in their local contexts, ${ }^{7}$ and in numerous inquiries into single provinces and commanderies of the military orders. ${ }^{8}$ Thomas Krämer's recent book, focusing on conflict between the orders and the bishops and its resolution, offers comparison between the Hospitaller and Templar provinces in Provence and the Teutonic bailiwick of Franconia, in southern Germany.9

Contextual differences taken into account, it is still possible to identify comparable developments and elements in common between apparently separate realities; such as, for example, the Templar Order in the Holy Land at the end of the twelfth century, and the Brethren of Santiago in Extremadura in the first half of the following century. Consequently, an overall study of this topic will be of use, by drawing examples from both the eastern and western regions. This paper will also examine two historical contexts closely: the Kingdom of Sicily, where the relations between the military orders and bishops have never been studied on their own, and Portugal, where the local possessions of the Templars remain less known from this angle than in Aragon and Castile. Two apparently very different historical contexts will thus be approached together.

3 Jonathan Riley-Smith, The Knights Hospitaller in the Levant, c. 1070-I309 (Basingstoke etc: Palgrave Macmillan, 2012), I 56-165; Pierre-Vincent Claverie, L'ordre du Temple en Terre Sainte et à Chypre au XIIIe siècle (Nicosia: Centre de Recherche Scientifique, 2005), I 44- I 70.

4 Philippe Josserand, Église et pouvoir dans la Péninsule Ibérique. Les ordres militaires dans le royaume de Castille (I252-I36g) (Madrid: Casa de Velázquez, 2004), I09-I I I.

5 Damien Carraz, L'Ordre du Temple dans la basse vallée du Rhône (II24-I3I2). Ordres militaires, croisades et sociétés méridionales (Lyon: Presses Universitaires de Lyon, 2005), I 33-I 54; Jochen Schenk, Templar families: landowning families and the Order of the Temple in France, c. II 20-I307 (Cambridge-New York: Cambridge University Press, 20I2), 80-83; id., "Aspects and Problems of the Templars' Religious Presence in Medieval Europe from the twelfth to the early fourteenth Century," Traditio 7 I (2016), 273-303.

6 See several passages in: Gregory O'Malley, The Knights Hospitaller of the English Langue, I460- Is65 (Oxford: Oxford University Press, 2005).

7 See for example: Luis Corral Val, "La Orden de Alcántara: organización institucional y vida religosa en la edad media," (PhD Diss., Universidad Complutense Madrid, I 998), 284-342.

8 See among others: Elena Bellomo, The Templar Order in North-West Italy (I 142-C.I330) (Leiden-Boston: Brill, 2008), I 48-1 53; Zsolt Hunyadi, The Hospitallers in the medieval Kingdom of Hungary, c. II50-1387 (Budapest: Central European University Press, 20 I O), I 66-I 72.

9 Thomas Krämer, Dämonen, Prälaten und gottlose Menschen. Konflikte und ibre Beilegung im Umfeld der geistlichen Ritterorden (Berlin-Münster: LIT, 20I6), passim. Krämer's work on the subject is certainly the most exhaustive, even if it concentrates only on conflicts, having the added advantage of being inserted in global research on conflicts and their resolution. 
This paper does not pretend to be exhaustive, as the existing primary and secondary sources on the topic are numerous. For want of space, the information available will be the object of selection, with some of the better-documented areas, like Navarre and Roussillon, being left aside. Records from the twelfth and the thirteenth centuries - the oldest surviving - will be given preference. In essence, this works aims to propose models and concepts that may apply to various contexts and eras.

\section{FRIENDLY RELATIONS AND PACIFIC COEXISTENCE}

In most cases and for most territories, the military orders' first steps owed much to episcopal support. Some prelates, like those who acknowledged the foundation of the Templar Order at the Council of Troyes in I I 29, or Albert, bishop of Riga, who promoted the Fratres Militie Christi (Brethren of the Sword) of Livonia in I 202, ${ }^{10}$ or yet still the Iberian bishops of the Reconquista who propped up new orders such as Alcántara, Calatrava and Santiago, ${ }^{\text {II }}$ played an important, sometimes crucial, part in the creation and institutionalisation of the orders.

Many bishops would encourage the orders to settle in their dioceses, confirming their possessions and giving them lands, churches, incomes, exemption from taxes and other rights. To give a few examples, the Templars were backed in the first half of the twelfth century by the bishops of Angers, Noyon, Soissons, Tarragona, Châlons sur Marne, Saragossa, Vaison, Tarazona and many others, ${ }^{12}$ while the

Io See: Friedrich Benninghoven, Der Orden der Schwertbrüder. Fratres Milicie Christi de Livonia (Cologne-Graz: Böhlau, 1965), 62-63 and passim. The degree of participation of Albert, absent from Livonia at the moment of the order's foundation, is not clear, but after his return he confirmed the existence of the Brethren of the Sword, see: Klaus Militzer, "Porte-Glaive, ordre des," in Prier et combattre. Dictionnaire européen des ordres militaires au Moyen Age, ed. Nicole Bériou and Philippe Josserand (Paris: Fayard, 2009), 729-730, here 729.

in Derek Lomax, La Orden de Santiago, Escuela de estudios medievales. Estudios 38 (Madrid: Consejo Superior de Investigaciones Científicas, Escuela de Estudios Medievales, I 965), 23-26 [Ist edition: Derek Lomax, The Order of Santiago, II70-1275 (Oxford: The Confraternity of Saint James, I 960)]; Sophia Menache, "La orden de Calatrava y el clero andaluz (siglos XIII-XV)," in Estudios en memoria del profesor don Claudio Sánchez-Albornoz, vol. I, ed. Miguel Angel Ladero Quesada, En la España Medieval 5 (Madrid: Universidad Complutense, 1986), 633-653, here 634, Corral Val, "La Orden," 290.

I2 Cartulaire général de l'Ordre du Temple IIIg?-II so: recueil des Chartes et des Bulles relatives à l'Ordre du Temple formépar le Marquis d'Albon, ed. Guigues Alexis Marie Joseph André d'Albon (Paris: Honoré Champion, I 91 3), I 5-I 6 no. 2 I; 23-24 no. 3 I; $42-43$ no. 59; 53-55 no. 7 I; 58-59 no. 75; 70-7I no. 94; I 00 no. I 42; I I 5-II 6 no. I66; I60-I 6I; no. 238, 2 I 8 no. 334; $235-236$ no. 368-369; 246-247 no. $391 ; 307$ no. $495 ; 310$ no. $501 ; 315$ no. 5 I o. It will not be 
Hospitallers were supported by the patriarchs of Jerusalem (Arnulph of Rohes) and Antioch (Bernard of Valence), by the archbishop of Caesarea, by the bishops of Nazareth, Tripoli and Beirut, as well as by many prelates of the West, like in Esztergom $^{13}$, Tarazona, Lleida and elsewhere. ${ }^{14}$ The Brethren of Santiago benefited in the last decades of the twelfth century from support of the archbishops of Compostela, ${ }^{15}$ the Order of Alcántara was originally promoted by both the archbishops of Compostela and of Braga, not to mention a series of local bishops, like those of Salamanca, Coria, Lamego and Viseu. ${ }^{16}$ Later on, in the beginning of the thirteenth century, the Teutonic Order was encouraged to settle in south Tyrol by the bishop of Trento ${ }^{17}$ and received lands, revenues and privileges from the bishops of Trier, Metz, Cologne, Utrecht and Liège. ${ }^{18}$

In some circumstances, this support was given at a time when the orders had not yet been provided with papal privileges of exemption - a source of conflicts later on - as it has been noted by Jonathan Riley-Smith ${ }^{19}$ and Derek Lomax ${ }^{20}$, but in many other cases, the fact that orders were exonerated did not influence relations with the bishops. ${ }^{21}$ Damien Carraz and Jochen Schenk have singled out rea-

possible due to limitations of space to quote in this paper all the existing editions of the primary sources. Citations will thus be limited to the basic diplomatic collections of the military orders.

13 Hunyadi, The Hospitallers, 24 and 166.

${ }^{14}$ Cartulaire générale de l'Ordre des Hospitaliers de S. Jean de Jérusale, vol. I, ed. Joseph Marie Antoine Delaville le Roulx (Paris: Ernest Leroux, I 894-1 904), 9 no. 5; 25-26 no. 25; 28-29 no. 29; 68-70 nos. 71-72; 87-88 no. I00; 89 no. I02; I08-109 no. I 32; I 2 I-I 22 no. I 50; I II-I 52 no. I96; I9I-I92 no. 252. Already in the first quarter of the twelfth century, the master of the Hospital, Raymond du Puy, wrote a letter to all the bishops, abbots, canons and other ecclesiastics to thank them for magno beneficio vestrarum elemosinarum quas nobis misistis honorabiliter ad nostrum auxilium: Ibid., 38-39 no. 46.

is Bullarium equestris ordinis Sancti Iacobi de Spatha per annorum seriem nonnullis donationum et aliis interiectis scripturis congestum, ed. Antonio Francisco Aguado de Córdova, Alfonso Antonio Alemán y Rosales, and José López Agurleta (Madrid: Sumptibus eiusdem ordinis. Ex typographia Ioannis de Ariztia, I7 19), 5-6.

16 Bullarium Ordinis Militiae de Alcantara olim S. Juliani del Pereiro per annorum seriem nonnullis donationum, concordiarum et aliis interjectis scripturis congestum, ed. Ignacio José de Ortega y Cotes, José Fernandez de Brizuela, and Pedro Ortega Zuñiga y Aranda (Madrid: Ex typographia Antonij Marin. Sumpibus ejusdem ordinis 1 759), 7-9.

17 Francesco Filotico, Le origini del Baliato di Bolzano nel quadro del primo sviluppo dell'Ordine Teutonico (I200-I270) (Galatina: Congedo, 2015), 73.

18 Die Urkunden des Deutschordens-Zentralarchivs in Wien. Regesten, ed. Udo Arnold (Marburg: N. G. Elwert, 2006-2009), nos. 25, 53, 147, 257 an 396.

19 Riley-Smith, The Knights, I 62: "At first the bishops did much to help the Order, making gifts of property and freeing it from the payment of the tithes."

20 Lomax, La Orden, 23-26.

${ }_{21}$ Sometimes the bishop's support could be of such importance to cause embarrassment: in I 225 the Hospitaller prior in France made an official declaration affirming that he had not paid, 
sons for this continuity in a large part of the French territories: firstly, bishops and the Templars (and Hospitallers) came from the same social background and sometimes were even relatives; secondly, there was a direct link between the settlement of the military orders and the Reform of the Church carried out by some bishops. ${ }^{22}$ The latter observation is especially true of Provence, where support from the local archbishops and bishops (like those of Arles, Avignon, Uzès or Vaison), to the Templars and the Hospitallers was particularly evident.

It is not rare to find strong personal relationships existing between a prelate and an order: in the I I 30 and 40 os in Saint-Paul-Trois-Châteaux, the Templars were close to the bishop Pons de Grillon and his family, ${ }^{23}$ in Lincoln, where the dean of the local church, Philippe of Harcourt, later bishop of Bayeux, made a donation of personal properties to the Temple, ${ }^{24}$ or in Tarazona (Aragon), where the bishop Michael was close friends with the Temple. ${ }^{25}$ The brethren of the Teutonic Order were, at the beginning of the thirteenth century, close to the patriarch of Aquileia, Wolfger of Ellenbrechtskirchen, a man who can be considered among the founders of their order, establishing it in Friuli. ${ }^{26}$

In other cases, there was a direct link between episcopal action and princely politics. Between I I 73 and I I 75, the Hospitallers' master Jobert wrote to the archbishop of Reims, Henry, the brother of Louis VII of France, asking for assistance in installing the order within the archdiocese. ${ }^{27}$ It seems that the request was met, as in April I 75 Pope Alexander III confirmed a long list of possessions which the Hospitallers had received from the archbishop and from the bishops of Laon, Châlons, Cambrai, Sens, Paris, Troyes and Beauvais, and from the king of France. ${ }^{28}$ Shortly afterwards, Bretislav III, the bishop of Prague and a member of the ducal family of Bohemia, made an important donation to the Hospitallers. ${ }^{29}$ Walter of Palearia, bishop of Troia and Catania, who acted as a supporter of the Templars, Hospitallers and the Teutonic Knights in southern Italy at the beginning of the

promised nor loaned anything to the bishop of Langres to obtain the concession of the hospital of Mormant: Cartulaire générale de l'Ordre des Hospitaliers de S. Jean de Jérusale, vol. II, ed. Joseph Marie Antoine Delaville le Roulx (Paris: Ernest Leroux, I 894-I 904 ), 335 no. I 8 I 2.

22 Carraz, L'Ordre, I 35, I 46, Schenk, Templar families, 80.

23 Carraz, L'Ordre, i 34.

24 Cartulaire général de l'Ordre du Temple, ed. Albon, i 49 no. 207.

25 Ibid., 218 no. 334 and 235-236 nos. 368-369.

26 Kristjan Toomaspoeg, "La fondazione della provincia di 'Lombardia' dell'Ordine dei Cavalieri Teutonici (secoli XIII-XIV)," Sacra Militia. Rivista di storia degli ordini militari 3 (2003): I I I-I 59 , here I 20.

27 Cartulaire générale de l'Ordre des Hospitaliers, I, ed. Delaville le Roulx, 303-304 no. 438.

28 Ibid., 328-329 no. 478.

29 Ibid., 443-444 no. 66 I. 
thirteenth century, ${ }^{30}$ was also chancellor of the Kingdom of Sicily. Political alliances between prelates and orders were always possible, like the one signed in I 32 I between the masters of Santiago and Calatrava and Juan de Aragón, archbishop of Toledo, to "ensure the peace and commodity of kingdoms". ${ }^{1}$

It is frequent to find a bishop among the witnesses of the documents issued in the orders' houses. In some cases they collaborated with the clergy. In I I 38-39, an internal conflict in the church of Rennes was arbitrated by the bishop in Rome, in the Templars' house, ${ }^{32}$ and such uses of the houses of the military orders can be observed in different contexts of place and time. At the same time, good relations between bishops and the orders can be seen also in the granting of indulgences, a vast topic which falls outside this paper. ${ }^{33}$

Contemporary with cases of initial support and sincere collaboration, the military orders could obtain possessions and privileges also through negotiations and transactions with the bishops; in April I I 35 the Hospitallers became exempt from the payment of tithes in the diocese of Acre in return for abandoning claims over the northern portal of the cathedral, which had been built on grounds belonging to them. ${ }^{34}$ The orders and the bishops often agreed on exchanges of lands, churches and other properties, such as a transaction, in I i 86, between the Hospitallers and the bishop of Laon, ${ }^{35}$ or between the master of Calatrava and the bishop of

30 Norbert Kamp, Kirche und Monarchie im Staufischen Königreich Sizilien, vol. I, Prosopographische Grundlegung: Bistümer und Bischöfe des Königreichs I194-I266, part 2, Apulien und Kalabrien (München: Wilhelm Fink Verlag, 1975), 509-5 14; id., Kirche und Monarchie im Staufischen Königreich Sizilien, vol. I, Prosopographische Grundlegung: Bistümer und Bischöfe des Königreichs I194-I266, part 3, Sizilien (München: Wilhelm Fink Verlag, I 975), I I 22- I I 25 and I2IO-I2I5; Kristjan Toomaspoeg, "Gli insediamenti templari, giovanniti e teutonici nell'economia della Capitanata medievale," in Federico II e i cavalieri teutonici in Capitanata. Recenti ricerche storiche e archeologiche. Atti del Convegno internazionale (Foggia-Lucera-Pietra Montecorvino, IO-I3 gingno 2009), ed. Pasquale Favia, Hubert Houben and Kristjan Toomaspoeg, (Galatina: Congedo, 20 I 2), I 83-2 I 4, here I90-191.

31 Bullarium Ordinis Militiae de Calatrava per annorum seriem nonnullis donationum, concordiarum et aliis interjectis scripturis congestum, ed. Ignácio José de Ortega y Cotes, Juan Francisco Alvarez de Baquedano, and Pedro de Ortega Zuñiga y Aranda (Madrid: Ioannis de Ariztia, I 76 I), I $87-$ I 88.

32 Cartulaire général de l'Ordre du Temple, ed. Albon, i 07 no. I 53.

33 Axel Ehlers, Die Ablasspraxis des Deutschen Ordens im Mittelalter (Marburg: N. G. Elwert, 2007), nos. 3103, 3904, 3905; idem, "The use of indulgences by the Teutonic Order in the Middle Ages," in The Military Orders, vol. 3, History and Heritage, ed. Victor Mallia Milanes (Aldershot: Routledge, 2008), I 39-I 45.

34 Cartulaire générale de l'Ordre des Hospitaliers, I, ed. Delaville le Roulx, 94-95 no. I I 2.

35 Ibid., 486-487 no. 77 I. 
Orense (Galicia) in 12 I $5 .{ }^{36}$ It was not uncommon for the orders to cede to bishops lands and even churches they had received or constructed in episcopal cities, in return for more extensive possessions outwards. ${ }^{37}$ A good example of such transfers comes from Chartres where, in i 85 , the bishop Renaud de Bar and Roger de Moulins, master of the Hospitallers, agreed that the order was to give up its church and cemetery in Chartres and reduce its house there, obtaining a church in Villeconin in return..$^{38} \mathrm{~A}$ similar exchange was made in the same year in Winchester. ${ }^{39}$

As Damien Carraz has noted for Provence, ${ }^{\circ}$ using a rationale that can be applied to western Europe in general, during the foundation of the military orders and the following decades, bishops demonstrated three types of attitudes: as unconditional endorsers of the orders, as their opponents, and as prudent supporters who pondered carefully upon the location of new settlements, the privileges to be granted, and the relative position of their dioceses. It was usual for many regions that prelates, close to the military orders as they were, exercised a certain prudence when it came to granting them lands and privileges.

This consideration is especially true for the medieval Kingdom of Sicily. Southern Italy is a particular case regarding the relations between bishops and the military orders. For the orders, the region worked as a link between their East and West possessions, as it contained some of the most important crusading ports, like Barletta, Messina and Brindisi. ${ }^{41}$ Besides, the local Church had a very singular

36 Bullarium Ordinis Militiae de Alcantara, ed. Ortega y Cotes, Fernandez de Brizuela, and Ortega Zuñiga y Aranda, 19.

37 The same tendency to "keep away" the orders from the diocesan centers is attested also in Provence: Carraz, L'Ordre, i 45.

38 Cartulaire générale de l'Ordre des Hospitaliers, I, ed. Delaville le Roulx, 469 no. 7 I 9.

39 Ibid., $480-482$ no. 755 .

40 Carraz, L'Ordre, $\mathrm{I} 37-\mathrm{I} 38$.

${ }^{41}$ Raffaele Iorio, "Uomini e sedi a Barletta di Ospedalieri e Templari come soggetti di organizzazione storica", in Barletta crocevia degli Ordini religioso-cavallereschi medioevali. Seminario di Studio, Barletta I6 giugno Igg6, ed. Renato Paterno' Di Montecupo Melitensia 2. (Taranto: Centro Studi Melitensi, I 997), 7I-I I9; Hubert Houben, "Zur Geschichte der Deutschordensballei Apulien. Abschriften und Regesten verlorener Urkunden aus Neapel in Graz und Wien," Mitteilungen des Instituts für Österreichische Geschichtsforschung I07, no. I-2 (1 999): 50- I I ; Mariarosa Salerno, Gli ospedalieri di San Giovanni di Gerusalemme nel Mezzogiorno d'Italia (secc. XII-XV) (Taranto: Centro Studi Melitensi, 200 I), passim; Kristjan Toomaspoeg, Templari, passim; id., Les Teutoniques en Sicile (II97-I492) (Rome: École française de Rome, 2003), 1 05- 107 and passim; Mariarosa Salerno and Kristjan Toomaspoeg, L'inchiesta pontificia del 1373 sugli Ospedalieri di San Giovanni di Gerusalemme nel Mezzogiorno d'Italia (Bari: Adda Editore, 2008), passim; Kristjan Toomaspoeg, "L’Ordine Teutonico nel Mediterraneo: bilancio e prospettive di ricerca - Der Deutsche Orden im Mittelmeerraum: Bilanz und Forschungsperspektiven," in L'Ordine Teutonico tra Mediterraneo e Baltico: incontri e scontri tra religioni, popoli e culture - Der Deutsche Orden zwischen Mittelmeerraum und Baltikum. Begegnungen und Kon- 
structure, as the territory was divided into no less than 145 dioceses, quite often of small dimensions and importance, which were in fact submitted to the king. ${ }^{42}$ Prelates like the archbishops of Trani, Brindisi, Messina and Palermo often acted also as high ranking officials of the royal court, with corresponding influence and power. In Southern Italy, the military orders never enjoyed from the bishops rights as extensive as, for example, those granted in southern France. In fact, the local prelates never gave the orders privileges and most of the local commanderies of the Temple, Hospital and Teutonic orders were not officially recognised by the bishops, even if their settlement quite often owed to "silent" support from them.

An interesting example is Trani and the local archbishop, Bertrand (I I 56/57- I I 87). He had led a diplomatic mission in Constantinople and was a fervent supporter of the congregations of the Holy Land. He initiated the settlement of the orders of Saint Lazarus and the Temple in his diocese. ${ }^{43}$ However, the military orders were not settled in Trani, the archbishop's seat, but in the harbour city of Barletta without explicit foundation privileges. In the context of the church structures of Apulia, where almost every relevant city was also a bishop's seat, Barletta, an emerging city with an archpriest instead of a bishop, was an exception. Submitted to the authority of the archbishop of Trani, Barletta entered the second half of the twelfth century in conflict with its ecclesiastical superior. ${ }^{44}$ It could be that the bishops used the military orders in some way to obtain control over the rebel local authorities. At the same time, the Hospitaller house in Barletta, documented since

frontationen zwischen Religionen, Völkern und Kulturen, ed. Hubert Houben and Kristjan Toomaspoeg (Galatina: Congedo, 2008), 35-63; id., "I Templari nel Mezzogiorno e nelle isole," in I Templari. Grandezza e caduta della 'Militia Christi', ed. Giancarlo Andenna, Cosimo Damiano Fonseca and Elisabetta Filippini (Milan: Vita e Pensiero, 2016), 75-83; Mariarosa Salerno, "The military orders and the local population in Italy: connections and conflicts," in The Military Orders, vol. 6.2, Culture and Conflict in Western and Northern Europe, ed. Jochen Schenk and Mike Carr (London-New York: Routledge, 20 I 7), I 72 - I 82.

42 Cosimo Damiano Fonseca, "Le istituzioni ecclesiastiche e la conquista normanna. Gli episcopati e le cattedrali," in I caratteri originari della conquista normanna. Diversità e identità nel Mezzogiorno (I030-II30). Atti delle sedicesime giornate normanno-sveve, Bari, 5-8 ottobre 2004, ed. Raffaele Licinio and Francesco Violante (Bari: Edizioni Dedalo, 2006), 335-348; Hubert Houben, "I vescovi e l'imperatore," in Federico II nel Regno di Sicilia. Realtà locali e aspirazioni universali. Atti del convegno internazionale di studi (Barletta, I9-20 ottobre 2007), ed. Hubert Houben (Bari: Adda Editore, 2008), I73-I 88; Decimae. Il sostegno economico dei sovrani alla Chiesa del Mezzogiorno nel XIII secolo. Dai lasciti di Eduard Sthamer e Norbert Kamp, ed. Kristjan Toomaspoeg (Rome: Viella, 2009), 33-38.

43 Kamp, Kirche, I.2: 546.

44 Decimae, ed. Toomaspoeg, 242. 
I $58,{ }^{45}$ reaped benefits from its relationship with the bishop of Canne, a "virtual diocese" whose seat, the city of Canne, was in fact abandoned, so that the prelate had Barletta as his residence.

The fight opposing the archpriests of Barletta and the archbishops of Trani gave the military orders a certain margin of freedom they could not find in the other coastal cities of Apulia. To give an example, in I I 9 I the hospital founded in Brindisi by German crusaders and pilgrims, incorporated about a decade later in the Teutonic Order, had to accept the submission of its church to the local diocesan authorities and therefore to accept strong limitations to "parish activities". ${ }^{46}$ As a consequence, Templars, Hospitallers and Teutonic Knights made Barletta - not Brindisi, despite its more important port - one of their headquarters in the Kingdom of Sicily.

Trani provides a clear example of the episcopal use of the military orders as a political tool, in the same way as the prelates of southern France as presented by Carraz and Schenk, or those of South Tyrol, where the Teutonic Order received several parish churches in the thirteenth century, for example in Sterzing and Lengmoos, with the agreement (if one follows the recent theory of Francesco Filotico) of the bishops, who exploited the order in their fight against the secular clergy and the local lay powers. ${ }^{47}$

Returning to the Kingdom of Sicily, two elements should be underlined. First of all, not every bishop was influential, so we find many prelates at the head of tiny dioceses, whose yearly revenues were sometimes just enough to buy a horse. Existing studies on the presence of the military orders in Sicilian provinces like Capitanata have proven that the Templars, Hospitallers and Teutonic Knights dominated the local Church economy at the expense of older monastic congregations and probably also of the bishops. ${ }^{48}$ Secondly, provinces of the military orders such as the Teutonic bailiwicks of Apulia and Sicily, the Hospitaller priories of Messina and Barletta, and most probably also the Templar province in the Adriatic part of Sicily, reaped more or less the same income annually as the "big" archbishops of Messina, Trani or Brindisi. ${ }^{49}$ Consequently, the orders could impose on small-

45 Codice diplomatico barese, vol. 9.I, I documenti storici di Corato (I046-1327) ed. Giovanni Beltrani (Bari: Società Storia Patria Bari, I 923 ), 62 no. 53.

46 See: Hubert Houben, "Auf dem Weg ins Heilige Land. Deutsche Pilger, Kreuzfahrer und Ordensritter in Italien," in Die Kreuzzugsbewegung im römisch-deutschen Reich (II.-I3-Jahrhundert), ed. Nikolas Jaspert and Stefan Tebruck (Ostfildern: Jan Thorbecke, 20 I6), I 03-I I 8 , here I I I-I I 2 .

47 Filotico, Le origini, I75- 176.

48 Toomaspoeg, "Gli insediamenti," 204-208.

49 For the direct incomes of the bishops of the kingdom see: Decimae, ed. Toomaspoeg, $75-79$ and fig. 3, 536-539. For those of the military orders, see: Anthony Luttrell, "Introduzione ge- 
er bishops, acting on the same level as the archbishops in a situation of open competition. This explains why (Bertrand of Trani and Walter of Palearia left aside) we do not find important promoters of the military orders among the south Italian clergy.

\section{Conflicts}

The intense activities of the military orders quickly led to clashes with the secular clergy. In fact, the same can be said about the disputes with other monastic communities, which are documented since early. These rarely went beyond the local or regional level..$^{\circ}$ Sometimes the disputes implicated the local canons or priests, like in Leffinge (diocese of Tournay) opposing the Templars in the mid-twelfth century $^{\text {sI }}$, or Uclès (diocese of Cuenca) where an agreement with the Brethren of Santiago was reached in $\mathrm{I}_{209^{52}}$, or yet still the chapter of Alba in Piedmont, coming in dispute with the Templars in $1217^{53}$. However, these confrontations mostly opposed a master, prior or commander of an order to the local bishop.

The first conflicts to involve the Hospitallers took place around I i 25 , before the militarisation of the order. ${ }^{54}$ They grew more intense from the mid-century, 55 which was also when the first serious clashes between the Templars and the local diocesan powers happened. The Spanish orders, founded later, first started entering into disputes with the prelates at the turn of the twelfth century: Santiago shortly

nerale," in L'inchiesta pontificia del 1373 sugli Ospedalieri di San Giovanni di Gerusalemme nel Mezzogiorno d'Italia, ed. Mariarosaria Salerno and Kristjan Toomaspoeg (Bari: Adda Editore, 2008), 7-30; Kristjan Toomaspoeg, La contabilità delle Case dell'Ordine Teutonico in Puglia $e$ in Sicilia nel Quattrocento (Galatina: Congedo, 2005), xlix-lxviii, lxxxix-xcvi; for the Templars no precise numbers are available, see: Kristjan Toomaspoeg, "Le grenier des Templiers. Les possessions et l'économie de l'Ordre dans la Capitanate et en Sicile," in L'économie templière en Occident. Patrimoines, commerce, finances. Actes du colloque international (Troyes-Abbaye de Clairvaux, 24-26 octobre 2012), ed. Arnaud Baudin, Ghislain Brunel and Nicolas Dohrmann (Langres: D. Guéniot-Conseil général de l'Aube, 2013), 93-I I 3.

so See some early examples of conflicts with monasteries in: Cartulaire général de l'Ordre du Temple, ed. Albon, 298-299 no. 476-477 and 337-339 no 550-552.

51 Ibid., 352 no. 569.

s2 Bullarium equestris, ed. Aguado de Córdova, Alemán y Rosales, and López Agurleta, 55-57.

53 Bellomo, The Templar Order, 29.

54 Cartulaire générale de l'Ordre des Hospitaliers, I, ed. Delaville le Roulx, 69-70 no. 72.

ss Ibid., I 3 I no. I 64. 
before I I $8 \mathrm{I}^{56}$, Calatrava before I $22 \mathrm{I}^{57}$, and Alcántara before $\mathrm{I} 227^{58}$. The Teutonic Order had suffered episcopal excommunications and interdicts sometime before I 2 I 8", while the Brethren of the Sword of Livonia clashed with the bishop of Riga not much later after it was founded, in any case before $1213^{60}$. Thereafter, conflicts were extremely frequent and can be explained by the growth of the military orders which made them formidable competitors against the local secular churches. The reasons and shapes of such confrontations have been singled out and examined by authors like Luis Corral Val, Jonathan Riley-Smith, Pierre-Vincent Claverie, and Thomas Krämer, showing that issues were similar despite local differences.

One reason for conflict were the usurpations carried out by the orders. Among the best known cases is that of Tartus, in the Holy Land, ${ }^{61}$ where, shortly before I 225, the Templars had moved onto the border columns separating their territory from the bishop's, besides building in the usurped area two churches which exercised parish activities, keeping all the ecclesiastical incomes for themselves. ${ }^{62}$ In the Iberian Peninsula, namely in Andalusia and Extremadura in the second half of the twelfth and the first half of the thirteenth century, the orders of Alcántara, Calatrava, Santiago, and the Temple rushed to the territories conquered from the Muslims, acquiring lands, building churches and founding and populating cities and villages in competition with the local diocesan structures, in a sort of "Far West" condition, ${ }^{63}$ sometimes with help from the secular powers. ${ }^{64}$ In common between the Latin East and the Iberian Peninsula was the necessity from the military orders and the bishops to seek out lands, revenues and settlers in relatively poor and depopulated areas. In Iberia, the dioceses in Andalusia, Extremadura, and Portugal

s6 Bullarium equestris, ed. Aguado de Córdova, Alemán y Rosales, and López Agurleta, 25-26.

57 Bullarium Ordinis Militiae de Calatrava, ed. Ortega y Cotes, Alvarez de Baquedano, and Ortega Zuñiga y Aranda, 52.

s8 Bullarium Ordinis Militiae de Alcantara, ed. Ortega y Cotes, Fernandez de Brizuela, and Ortega Zuñiga y Aranda, 28.

59 Tabulae Ordinis Theutonici. Ex tabularii regii Berolinensis codice potissimum, ed. Ernst Strehlke (Berlin: Weidmann, I 869), 275 no. 305.

60 Liv-, Esth-und Curländisches Urkundenbuch nebst Regesten, vol. I. I, ed. Friedrich Georg von Bunge (Reval (Tallinn): Kluge und Ströhm, I 853), no. 3 I (column 38 ).

${ }_{61}$ For the conflicts between the bishops of Tartus and the Hospital, see: Riley-Smith, The Knights, 163.

62 Claverie, L'ordre, I 45 - I 46.

63 Juan Luis de la Montaña Conchiña, "Obispados y órdenes militares. Problemas jurisdiccionales en la Transierra extremeña del siglo XIII," Alcantara. Revista del Seminario de Estudios Cacereños 34, no. I (1 995): 29-48, here 29-30.

${ }_{64}$ For example, Santiago in Trujillo (Extremadura) in I 1 86, receiving episcopal rights and tithes directly from King Alphonse VIII of Castile: Bullarium equestris, ed. Aguado de Córdova, Alemán y Rosales, and López Agurleta, 33. 
were often founded or recreated in simultaneous with the settlement of the military orders. ${ }^{65}$ Elsewhere in the West, usurpations were more sporadic. In the Kingdom of Sicily, between I 98 and I 2 I 5 (during the early years of King Frederick), Templars, Hospitallers and Teutonic Knights all carried out every usurpation and abuse imaginable, making up about half of their later patrimony. ${ }^{66}$ The I 373 papal enquiry on the Hospitallers, an excellent source on the relations between the military orders and the bishops, indicates some cases of conflict, like the bishop of Cefalù, in Sicily, disputing the usurpation of the Premonstratensian abbey of Gratteri and some other lands of the Church. ${ }^{67}$

The issue of usurpations includes cases where the orders took possession of territories in legal ways, but failed to have their rights recognised by the local churches. In Portugal, in the framework of the crusade destined to conquer Lisbon, ${ }^{68}$ the Templars obtained in I 47 from King Afonso Henriques all the ecclesiastical rights in the city of Santarém, the new residence of the royal court. This privilege was contrary to the interests of the bishop of Lisbon, the Englishman Gilbert of Hastings, and in I I 59 an agreement was made between the king, the bishop and the Templars who transferred to Hastings their rights and properties in Santarém, obtaining from the king in return vast territories in central Portugal, exemption from ecclesiastical taxes, and the permission to build new churches. ${ }^{69}$ This agreement was at once recognised by the papal court of Hadrian IV and his successors, making the creation of what was one of the biggest and richest Templar territories in the West possible. In this area, Lower Beira today, the order built a series of castles and founded a number of cities submitting exclusively to Templar authority. ${ }^{70}$

In this way a sort of nullius diocesis of the Temple was created, but from the legal point of view the agreement of I I 59 was incorrect, since the greater part of those territories belonged not to the diocese of Lisbon but Coimbra, which was subject to the archbishop of Braga. In fact, in I I 59 the seat of Coimbra was vacant,

6s Montaña Conchiña, "Obispados," 3 I.

66 Toomaspoeg, Templari, 57-63.

67 Salerno and Toomaspoeg, L'inchiesta, I 23 - I 24.

68 Jonathan Phillips, "Ideas of Crusade and Holy War in De expugnatione Lyxbonensi (The Conquest of Lisbon)," in Holy Land, Holy Lands, and Christian History, ed. Robert N. Swanson (Woodbridge: Boydell \& Brewer, 2000), I 23-I 4 I; Alan J. Forey, "The Siege of Lisbon and the Second Crusade," Portuguese studies 20 (2004): I - I 3.

69 Monumenta Henricina, vol. I, ed. Manuel Lopes de Almeida, Idalino Ferreira da Costa Brochado, and Antonio Joaquim Dias Dinis (Coimbra: UC Biblioteca Geral I, I 960), 5-9 no. 3.

70 Kristjan Toomaspoeg, "The Marquis of Albon, Carl Erdmann and the Templar Sources in Portugal," in The Templars and their Sources, ed. Karl Borchardt, Karoline Döring, Philippe Josserand, and Helen J. Nicholson (New York: Routledge, 2017), I06-I 22, here I09-I I 0. 
as the bishop had been deposed and the successor elected only in $1161,{ }^{71}$ while the archbishop of Braga was a staunch ally of King Afonso Henriques and had participated in the crusade of 1 I $47 . .^{72}$ Later bishops of Coimbra did not accept the fact that their diocese had been reduced to one third to the benefit of the Templars and initiated a lawsuit leading to long negotiations in the papal court. Initially, at the beginning of the I I 80 s, they had success, the archbishop of Braga and the bishop of Porto even commending the newly-built Templar churches of the area to papal interdict. ${ }^{33}$ Urban III, however, decided in favour of the Templars in I I 86 - I I $87,,^{74}$ a decision confirmed by Celestine III in I $196 .{ }^{75}$ Under Innocent III the papal curia understood that, in effect, an error had been made in I I 59 , thereby ordering the opening of a new process on the matter. ${ }^{76}$ Meanwhile, the papal interdict on the templar churches was renewed. ${ }^{77}$ In 1199 the situation became much more complicated, as the bishop of Coimbra was no longer alone in his plea against the Templars, with his colleagues in Lamego, Lisbon, and Viseu also advancing claims on parts of the territory in question..$^{78}$ Evidently, this confusion benefited the Temple, which in 1217 obtained from Honorius III confirmation of the former papal privileges following the agreement of I $159 .{ }^{79}$

Thus, conflicts sometimes stemmed from the usurpations perpetrated by the military orders and generally by their overpowering attitude, like when the Hospitallers faced and defeated the patriarch of Jerusalem, Fulcher of Angoulême, causing the reaction of authors like William archbishop of Tyre, ${ }^{80}$ or when the Brethren of Calatrava imposed illegal tolls in the archdiocese of Toledo, around I $245{ }^{.1}$

${ }_{71}$ Pius Bonifacius Gams, Series Episcoporum Ecclesiae Catholicae, vol. I (Leipzig: Manz, I 873), 96.

72 Rodrigo Cunha, Da Primeira parte da historia ecclesiastica dos arcebispos de Braga e dos Santos e Varoes illustres (Braga: Manoel Cardozo, I634), 56-68.

73 Papsturkunden in Portugal, ed. Carl Erdmann (Berlin: Weidmannsche Buchhandlung, 1927), 287-288 no. 98.

74 Ibid., 300-301 no. 107 and 30I-302 no. 108 .

75 Ibid., 372 no. I 50.

${ }^{6}$ Patrologiae Cursus Completus: Series Latina, vol. 2 I 4, Innocentius III Pontifex Romanus, ed. Jacques Paul Migne (Paris: apud J.-P. Migne I 855), no. 22 I (cols. I9 I-I 92 ).

77 Bulário Português. Inocêncio III (II 8 - I2I 6), ed. Avelino de Jesus da Costa and Maria Alegria F. Marques (Coimbra: Instituto nacional de investigação científica, I 989), 38, no. 28.

${ }_{78}$ Patrologiae, 2 I 4, ed. Migne, no. 196 (cols. 743-745).

79 Peter Linehan, Portugalia Pontificia: Materials for the history of Portugal and the papacy I $198-$ -1417 , vol. I (Lisbon: Fundação Calouste Gulbenkian, 2013), I I-I 52 no. IOI and I 53 no. I04.

8o Riley-Smith, The Knights, I 56; William accused the Templars and Hospitallers of "ingratitude": Krämer, Dämonen, I 06.

81 Bullarium Ordinis Militiae de Calatrava, ed. Ortega y Cotes, Alvarez de Baquedano, and Ortega Zuñiga y Aranda, 78-82. 
However, the main reasons for confrontation with the bishops were the direct submission of the military orders to the papal see and their specific privileges. This subject has been treated in depth by many authors. ${ }^{82}$ It is sufficient to remember, as Thomas Krämer has noted for the three major orders, that obtaining the exemption was neither linear nor a fast process: the Hospitallers were given complete exoneration from the bishop's jurisdiction in I I 53 , the Templars in I 179, while the Teutonic Order, founded at the beginning of the pontificate of Innocent III, had to wait until Innocent's successor, Honorius III, to gain such rights. ${ }^{83}$ Thus, the three orders received much earlier the release from tithes collected not only on the newly-conquered lands (novalia) ${ }^{84}$ but also on the other territories they cultivated for their own use (labores). ${ }^{85}$

If we take a closer look at the other military orders, we see that Calatrava was taken under the protection of the Apostolic See becoming exempt from tithes in I $164,{ }^{86}$ and Santiago in I $173,{ }^{87}$ receiving in 1175 exemption from episcopal jurisdiction in newly-conquered lands ${ }^{88}$ while the Order of Alcántara was granted exemption from all tithes on the lands cultivated for its own use already at the moment that the order was approved by Alexander III in I $77 .^{89}$ The same rights were conferred also on Mountjoy in I I $80.9^{\circ 0}$ In I 20I, the privileges of Calatrava were given also to the Order of Évora in Portugal.9r The Brethren of the Sword of Livonia, being subject to the local bishops, were taken under the direct protec-

82 See for example: Luis García-Guijarro Ramos, "Exemption in the Temple, the Hospital and the Teutonic Order. Shortcomings of the Institutional Approach," in The Military Orders, vol. 2, Welfare and Warfare, ed. Helen J. Nicholson (Aldershot: Routledge, I 998), 289-293; the most complete synthesis is given in Krämer, Dämonen, 85 - I 59 .

83 Krämer, Dämonen, i 58.

${ }_{4}$ The same applies to the Spanish orders: in I I 8 I Lucius III prohibited the Castilian prelates to impose payment of tithes on churches builded by Santiago "in the desert" and to throw interdicts and excommunications on the order's villages de frontaria: Bullarium equestris, ed. Aguado de Córdova, Alemán y Rosales, and López Agurleta, 25-26.

85 Krämer, Dämonen, I 62-I 75: the Templars received this privilege in I 1 39, the Hospitallers already in I I 3 , the Teutonic Order in I 96 (before its official foundation) for the novalia and in 1220 for other lands.

86 Bullarium Ordinis Militiae de Calatrava, ed. Ortega y Cotes, Alvarez de Baquedano, and Ortega Zuñiga y Aranda, 5-6.

87 Bullarium equestris, ed. Aguado de Córdova, Alemán y Rosales, and López Agurleta, io.

88 Ibid., I3-17.

89 Bullarium Ordinis Militiae de Alcantara, ed. Ortega y Cotes, Fernandez de Brizuela, and Ortega Zuñiga y Aranda, 3-4.

90 Bullarium Ordinis Militiae de Calatrava, ed. Ortega y Cotes, Alvarez de Baquedano, and Ortega Zuñiga y Aranda, I 4-ı 6.

91 Ibid., 36-37. 
tion of the pope only in $1228,,^{92}$ but since their beginning were already exonerated from tithes and had their own territory. ${ }^{93}$ As it has been noted, the privileges of the military orders were not as original as it could seem and there is resemblance to be found especially with the Cistercians. In fact, the Order of Calatrava was exonerated from episcopal jurisdiction first of all thanks to its dependency on the Cistercian Order. ${ }^{94}$ As late as 1 258, Alexander IV noted that the Brethren of Alcántara, as all the Cistercians, were exempt from the payment of tithes, ${ }^{95}$ and in 1265 Clement IV used the same arguments to defend the Temple. ${ }^{96}$

The clashes between bishops and the orders had often - if not mainly - purely economical reasons. ${ }^{97}$ The payment of tithes was among the most frequent. This question was especially important in the Iberian Peninsula and in western and central Europe, ${ }^{98}$ and less in regions such as the Holy Land. ${ }^{99}$ In the Kingdom of Sicily, for example, a tithe collecting system did not exist as such, and the churches roused the so-called "state tithes" consisting of parts of the fiscal and juridical revenues of the crown. ${ }^{100}$ In no case were tithes a reason for confrontation between the bishops and the military orders. Circumstances were very different in territories like Andalusia and Extremadura ${ }^{101}$, but also Hungary ${ }^{102}$, where in effect most conflicts originated in the issue of tithes. The problem raised when the orders refused to deliver a part of the tithes (normally the episcopalia pars of one fourth, or the tertia pontificale of one third, but sometimes as much as one half) to the bishop, or when the bishop claimed more. In other cases, the bishops desired to collect tithes on the novalia, the newly conquered lands, thus transgressing the orders' privileges. ${ }^{103}$

In Castile, Portugal, and some other regions, the issue of tithes related in some way to another privilege of the military orders, the right of building churches and

92 Liv-, Esth-und Curländisches Urkundenbuch, I.I, ed. Bunge, no. 99, cols. I I 7- I I 8.

93 Benninghoven, Der Orden, 6 I-63; Militzer, "Porte-Glaive," 729.

94 Menache, "La orden," 638.

95 Bullarium Ordinis Militiae de Alcantara, ed. Ortega y Cotes, Fernandez de Brizuela, and Ortega Zuñiga y Aranda, 96-98.

96 In Cum abbates Cisterciensium of June 8, see: Linehan, Portugalia, 423 no. 649.

97 Montaña Conchiña, “Obispados," 29; Krämer, Dämonen, 608.

98 See for example the case of the diocese of Györ in Hungary, where the bishop forced the Hospitallers to pay tithes before March I 208: Hunyadi, The Hospitallers, I 66-I 72.

99 Riley-Smith, The Knights, 162.

100 Decimae, ed. Toomaspoeg, 45-90.

${ }_{101}$ Montaña Conchiña, "Obispados," 29; Corral Val, "La Orden," 286.

${ }_{102}$ Hunyadi, The Hospitallers, 167.

${ }_{103}$ Bullarium Ordinis Militiae de Calatrava, ed. Ortega y Cotes, Alvarez de Baquedano, and Ortega Zuñiga y Aranda, 86; Bullarium Ordinis Militiae de Alcantara, ed. Ortega y Cotes, Fernandez de Brizuela, and Ortega Zuñiga y Aranda, 96. 
chapels in the newly-conquered lands. In those territories, this often implied that the orders tried to subtract villages and urban centers from the bishops' jurisdiction. To give one example, the Templars of Portugal founded cities such as Tomar, Pombal, and Castelo Branco, granting them privileges. ${ }^{104}$ In July I 2 I 9 the masters of Calatrava and of Alcántara, in the presence of the local bishop, conceded a village in the diocese of Salamanca the privilege of foundation, stipulating that the inhabitants ought to pay tithes to the orders and to be buried in the local cemetery. ${ }^{105}$

In most of eastern and western Europe, the bishops clashed with the military orders on the question of burial rights, legacies and donations. In the beginning, the orders received the right to have cemeteries and to bury their own brethren ${ }^{106}$ and familiars ${ }^{107}$, but the privilege was then expanded in a way that anybody could choose burial in the cemetery of a military order. The Hospitallers enjoyed this possibility from $1 \mathrm{I} 79,{ }^{108}$ and the same right was included in the first general papal privileges granted to the Iberian orders. ${ }^{109}$ Burial became the object of strong contestation: ${ }^{110}$ the Templars and the Hospitallers had the reprehensible habit of burying excommunicants, sometimes their familiars and friends, ${ }^{111}$ sometimes the inhabitants of their estates, ${ }^{112}$ which often provoked a reaction from the bishops and the papacy. ${ }^{113}$ This accusation was one of the strongest against the two orders

${ }_{104}$ Toomaspoeg, "The Marquis," I I 0.

ros Bullarium Ordinis Militiae de Alcantara, ed. Ortega y Cotes, Fernandez de Brizuela, and Ortega Zuñiga y Aranda, 2 I - 22.

${ }_{106}$ Cartulaire général de l'Ordre du Temple, ed. Albon, I 5-1 6 no. 2 I; on this point, contestations were relatively rare. Notice when in I I 64- I 165 the bishop of Sens impeded the burial of a Hospitaller, see: Cartulaire générale de l'Ordre des Hospitaliers, I, ed. Delaville le Roulx, 233-234 no. $33 \mathrm{I}$.

${ }_{107}$ Krämer, Dämonen, 228-229.

${ }_{108}$ Riley-Smith, The Knights, i 58.

109 Bullarium Ordinis Militiae de Alcantara, ed. Ortega y Cotes, Fernandez de Brizuela, and Ortega Zuñiga y Aranda, 12 and 42-45.

1 10 See the case of Castile in Josserand: Église, ı о9- г о ; see also: Corral Val, "La Orden," 288.

${ }^{11}$ In February I 2 I 2, Innocent III prohibited both Templars and Hospitallers to give burial to the family members of their confratres of the diocese of Geneva, under the interdict: Cartulaire générale de l'Ordre des Hospitaliers, II, ed. Delaville le Roulx, I 37 no. I 376. In October I 234 Gregorius IX had to amonish the Templars of the diocese of Braga who had continued to bury noblemen excommunicated for aggressions against churches and monasteries: Régistres de Grégoire IX, ed. Lucien Auvray, vol. I (Paris: Albert Fontemoing, I 896), I I 58 no. 2 I 54.

${ }_{112}$ Like those of the Hospital in Tortosa in Catalonia in I 99 (Cartulaire générale de l'Ordre des Hospitaliers, I, ed. Delaville le Roulx, 67 I no. 1079), or in Corbie in Champagne in I 2 I 2: Cartulaire générale de l'Ordre des Hospitaliers, II, ed. Delaville le Roulx, I 46- I 47 no. I 392.

113 So in March I 75 Alexander III ordered that the Hospitallers and Templars of the archdiocese of Canterbury had to dig out the excommunicants buried in their cemeteries: ibid., 327 no. 476. 
during the III Lateran Council of I $179 .{ }^{114}$ The orders were also accused of allowing excommunicants into mass, of conferring them sacraments, and of abusing the privilege of celebrating liturgy in the orders' churches during periods of interdict, once a year, behind closed doors and without sounding the bells, and to collect alms on that occasion. ${ }^{115}$

Most of the bishops did not welcome the orders to collect legacies and donations. In several cases, like with Calatrava in Seville in $1270,{ }^{116}$ the orders could bury "strangers" without paying taxes (or paying fewer taxes) to the bishop, but could not bury the inhabitants of the diocese, and they had to transfer a great part of their patrimony to the cathedral church. In other cases, the bishops sought to control the donations benefiting the military orders. This issue was the principal source of conflicts in the Kingdom of Sicily, where the bishops, with limited resources, reaped an important part of their incomes from legacies and donations.

A good example is a conflict between the Templars and the archbishops of Messina that ended in I 209 with a decision of the papal legate to allow the archbishop to have one fourth of the legacies made by the inhabitants of the city, as the order kept the legacies made by "strangers", as well as all weapons and horses. ${ }^{17}$ A compromise was found also in other cases, but in many local contexts the bishops succeeded in overcoming the military orders, like in Aqui in Piedmont, where Pope Urban III ( I I 85- I I 87) forbade the Templars to exercise "parish functions", mentioning specifically "public penitence" and the burial of the dead. ${ }^{118}$

The relationship between the military orders and the bishops evolved in time. In the beginning, the prelates held a certain power over the first communities of Templars, Hospitallers, Teutonic Knights and the Iberian orders, as shown in the orders' first rules and statutes. ${ }^{19}$ The orders then became more independent until

${ }_{14}$ Giovanni Domenico Mansi, Sacrorum Conciliorum nova et amplissima collectio, vol. XXII (Venice: Apud Antonium Zatta, 1778 (repr. Graz: Akademische Druck u. Verlagsanstalt, I 96I)), cols. 222-223; see: Riley-Smith, The Knights, r 60, Krämer, Dämonen, 606.

is Bullarium Ordinis Militiae de Alcantara, ed. Ortega y Cotes, Fernandez de Brizuela, and Ortega Zuñiga y Aranda, 42-45; Bullarium equestris, ed. Aguado de Córdova, Alemán y Rosales, and López Agurleta, I 3- 17; Bullarium Ordinis Militiae de Calatrava, ed. Ortega y Cotes, Alvarez de Baquedano, and Ortega Zuñiga y Aranda, I 4- I6 (Mountjoy), 64 (Calatrava), Menache, "La orden," 638, Riley-Smith, The Knights, I 56. Later, in I 224, the Templars and Hospitallers of the diocese of Arras were also accused of celebrating mass with excommunicated priests: Cartulaire générale de l'Ordre des Hospitaliers, II, ed. Delaville le Roulx, 3 I 9 no. I 783.

${ }_{116}$ Menache, "La orden," 645-646.

${ }_{117}$ Petracca, Giovanniti, II: 517-5 I 8; on the traditio cum equis et armis see: Krämer, Dämonen, 266-267.

${ }_{11} 8$ Bellomo, The Templar Order, 152.

119 For example, following chapter 6I of the Templars' Latin Rule (see: Simonetta Cerrini, "Une expérience neuve au sein de la spiritualité médiévale: l’ordre du Temple (I I 20-I 3 I 4). Étude 
the Third Lateran Council in I 179 and its canon 9. This was a turning point detrimental to the orders, but as Jonathan Riley-Smith has noted was softened by a series of decisions by Alexander III later on. ${ }^{120}$ The popes defended the military orders, but never overrode the episcopal rights. ${ }^{21}$

The bishops could still limit the orders' field of action through a series of rights they never stopped exercising. The orders needed prelates to consecrate their churches and ordinate their priests and chaplains. Moreover, in many cases the latter could be chosen by the orders but had to be confirmed by the bishops. There were differences between territories, as sometimes this obligation concerned only priests in churches under the orders' patronage or churches that came to them through concessions or donations, i.e., not constructed by them. ${ }^{122}$ In other cases, all priests had to be presented before the bishops. However, a series of privileges put the orders at liberty to choose freely the prelate before whom priests and chaplains were to be presented, liberating them from the power of the diocesan bishop. ${ }^{123}$ In some other cases, the priests were required to take part in synods and other official reunions as summoned by the bishop, together with the secular clergy, and they had to celebrate mass at the cathedral during important religious festivities. ${ }^{124}$

The bishops also imposed a series of local taxes on the military orders, such as the procuratio and the cathedratico, which were intended as the orders' official ac-

et édition des règles latine et française," (PhD Diss., Université de Paris IV-Sorbonne, I 997), I 48-I 49), the candidates in the West who desired to enter the order needed the agreement of their diocesan bishop.

${ }_{120}$ Riley-Smith, The Knights, 160.

${ }^{121}$ A good example is when, somewhere between II66 and I179, the Hospitallers protested against some bishops who had forced the order to deliver them one third of legacies. Pope Alexander III did not prohibit this practice, as the Hospitallers might have hoped, but he did limit the bishops' part to one fourth: Cartulaire générale de l'Ordre des Hospitaliers, I, ed. Delaville le Roulx, 248 no. 360.

${ }^{122}$ That was also the opinion at the papal see: Cartulaire générale de l'Ordre des Hospitaliers, I, ed. Delaville le Roulx, 207 no. 277.

${ }_{123}$ The Hospitallers were given this possibility in I 154 (Riley-Smith, The Knights, 1 56) and this was one of the basic rights of Alcántara (Bullarium Ordinis Militiae de Alcantara, ed. Ortega y Cotes, Fernandez de Brizuela, and Ortega Zuñiga y Aranda, 42-45) and Calatrava (Menache, "La orden," 638). Differently, in I 225, arbitrating the quarrel between the Brethren of the Sword and the bishop of Riga, the legate William of Modena decided that the priests of the order were responsible before the bishop, while the knights depended only from their master: Liv-, Esth-und Curländisches Urkundenbuch, I.I, ed. Bunge, no. 74, col. 79-80.

124 See for example: Bullarium Ordinis Militiae de Calatrava, ed. Ortega y Cotes, Alvarez de Baquedano, and Ortega Zuñiga y Aranda, 20; Cartulaire général de l'Ordre du Temple, ed. Albon, 345-346 no. 557; Menache, "La orden," 640; Montaña Conchiña, "Obispados," 4I; Krämer, Dämonen, i 17. 
knowledgment of the bishop. The former was a subvention paid to the bishop during the official visitations of the orders' churches, the latter being a regular annual tax. ${ }^{125} \mathrm{~A}$ special tax of investiture often had to be paid to every new bishop. For example, the Teutonic Order had to renew its rights periodically over a church in Stigliano, halfway between Treviso and Padua, paying a tax to the bishop of Treviso, ${ }^{126}$ while the Templars of north Italy paid the tax of investiture in Chieri, Pavia, Piacenza, and Tortona. ${ }^{127}$ This taxation was not always accepted by the orders, with violent conflicts ensuing. In I 292- I 293 the Brethren of Alcántara attacked the tax collectors of the bishop of Coria in Extremadura and tried to kill some of them. ${ }^{128}$ In the fourteenth and the fifteenth centuries, the bishops of south Italy, who previously had never exercised fiscal rights on the military orders, imposed on them taxes, like the Subsidium caritativum, that would give rise to a conflict between the Hospitallers and the archbishop of Messina.

A major problem was defining the exact number of people who could benefit from the orders' privileges ${ }^{129}$ : all of the orders' members were included, but the exact degree of membership was not always evident: beyond the priests, knights and squires, there were also numerous confratres and familiars that might ascend to hundreds of persons, as with the Hospitallers in Messina or the Teutonic Knights in Palermo. ${ }^{130}$ All those men and women participated in the orders' religious ceremonies and processions. In other cases, whole territories were under the control of an order, like parts of Andalusia and Extremadura where, in I 248, the Order of Calatrava received the right to distribute sacraments to its own "parishioners". ${ }^{131}$

The issue became manifest when the bishops started making use of the most important instrument at their disposal against the military orders: the capacity of promulgating sentences of excommunication and interdict. In some cases, those sentences hit directly the orders' brethren and their houses, ${ }^{132}$ even if the papacy

\footnotetext{
I25 Among many other examples, see: Montaña Conchiña, "Obispados," 4 I.

126 Toomaspoeg, "La fondazione," I 30.

127 Bellomo, The Templar Order, i 48-1 49.

${ }_{128}$ Montaña Conchiña, "Obispados," 4I.

129 Krämer, Dämonen, I 44.

${ }^{130}$ Kristjan Toomaspoeg, "'Confratres, procuratores, negociorum gestores et factores eorum...' Storia dei familiares dei Cavalieri Teutonici in Sicilia ( I 197-I 492)," Sacra Militia. Rivista di storia degli ordini militari I (2000): I 5 I- I65.

${ }^{131}$ Bullarium Ordinis Militiae de Calatrava, ed. Ortega y Cotes, Alvarez de Baquedano, and Ortega Zuñiga y Aranda, 86-87.

${ }_{132}$ For example, among numerous other cases, in 1234 in the archdiocese of Mainz: Die Urkunden, ed. Arnold, no. 220; for the Iberian Peninsula see for example: Corral Val, "La Orden," 289.
} 
had prohibited this practice, ${ }^{133}$ reducing also the power of its own legates - like in I 22 I, when Honorius III stipulated that the papal legates did not have full power on Calatrava (one of those being the archbishop of Toledo, who was in conflict with the order). ${ }^{134}$ Since the second half of the twelfth century, the target of the sentences of excommunication and interdict were often persons close to the military orders as well as collaborators. In i i 8 I Lucius III had to defend Santiago against the bishops of Castile who had excommunicated the persons living in the settlements they had founded on the Muslim "frontier" 135 ; in both I 240 and 1259 the popes admonished the archbishop of Compostela and his suffragans who had excommunicated persons using the mills and furnaces of the order of Alcántara ${ }^{136}$ : in $126 \mathrm{I}$ the archbishop of Sevilla was himself put under an interdict, because he had excommunicated persons connected to the Order of Calatra$\mathrm{va}^{137}$; and in 1268 some bishops of the Latin East excommunicated laymen serving the Hospitallers. ${ }^{138}$

In some cases, interestingly the conflicts with the bishops had personal grounds and concerned only one specific order. For example, in Trani in the Kingdom of Sicily the local archbishop - the same Bertrand who had supported the local house of the Templar Order - entered in the I I 8 os into a violent clash with the Hospitallers, forbidding them to make processions, ripping the crucifix from their church, and prohibiting, under penalty of excommunication, all the inhabitants of the diocese to attend mass in the Hospitallers' church and to make donations and wills to their benefit. He was assisted by one of his suffragans, the bishop of Salpi. ${ }^{139}$ This is the oldest example of conflicts between the military orders and the south Italian bishops. It continued under the successors of Bertrand, as in I 2 I 9 one of them was accused of having "plundered" a Hospitaller church and ex-

${ }_{133}$ Bullarium Ordinis Militiae de Calatrava, ed. Ortega y Cotes, Alvarez de Baquedano, and Ortega Zuñiga y Aranda, I4-16, 53, Cartulaire générale de l'Ordre des Hospitaliers, I, ed. Delaville le Roulx, 95-96 no. i I 3; 205 no. 272; Tabulae, ed. Strehlke, 275 no. 305; see also: Claverie, L'ordre, I 53.

134 Menache, "La orden," 638-639.

${ }^{135}$ Bullarium equestris, ed. Aguado de Córdova, Alemán y Rosales, and López Agurleta, 25-26.

${ }^{136}$ Bullarium Ordinis Militiae de Alcantara, ed. Ortega y Cotes, Fernandez de Brizuela, and Ortega Zuñiga y Aranda, 49-50, I03-104; Bullarium Ordinis Militiae de Calatrava, ed. Ortega y Cotes, Alvarez de Baquedano, and Ortega Zuñiga y Aranda, 70-7 I.

137 Bullarium Ordinis Militiae de Calatrava, ed. Ortega y Cotes, Alvarez de Baquedano, and Ortega Zuñiga y Aranda, I 20.

${ }_{138}$ Riley-Smith, The Knights, I 6 I.

139 Cartulaire générale de l'Ordre des Hospitaliers, I, ed. Delaville le Roulx, 508-509 nos. 8 I 6-8 I 7 ; Italia Pontificia, IX, Samnium-Apulia-Lucania, ed. Wather Holtzmann (Berlin: ZVAB, 1962), 298 nos. $32-37$ and 306 nos. $2-4$. 
communicated the benefactors of the order. ${ }^{40}$ What is interesting, this issue concerned only the Hospitallers and not the Templars who had a stronger presence in the archdiocese of Trani. In the opposite way, the archbishops of Messina were, in the beginning of the thirteenth century, in conflict with the Templars ${ }^{141}$ and not with the considerably more prosperous Hospitallers.

Reasons for predilection for one or another order were several, for example the fact that the local Genovese community helped the Hospitallers settle in Messina, while the Templars seem to have been backed by the Venetians, their local church being dedicated to St Mark. ${ }^{142}$ In all the dioceses, the local political circumstances also played a part in the relations between bishops and orders. The clash between the Hospitallers and the archbishop of Messina in 1344, described above, is quite exemplary from this point of view: the archbishop was a Catalan named by Clement VI (who was not exactly a "friend" of the Hospitallers). The pope had cancelled the previous election of Federico Guercio, made by the diocesan chapter. In I 344 , Guercio clearly sympathised with the Hospitallers in the city and an alliance was formed between the enemies of the archbishop Pujol and the Hospital.

The Messina example also shows how the tensions between the bishops and the orders remained a fact after the fall of Acre in I29 I and the Trial of the Temple. It is possible to think about a certain "stagnation" of relations, as the conflicts originated in the previous centuries were often still "open”, such as between Alcántara and the archbishops of Sevilla in $1426,{ }^{143}$ or between the Teutonic Order and the bishop of Trento in $1430 .^{144}$

\section{THE AGREEMENTS}

About a third of the recent monograph by Thomas Krämer, based on no less than 473 conflicts between the military orders and prelates in Provence and southern Germany, is dedicated to the solution of those disputes. He examines the role of the papal see in this process, the bilateral agreements between bishops and orders

${ }^{140}$ Cartulaire générale de l'Ordre des Hospitaliers, II, ed. Delaville le Roulx, 260-26 I no. I655. It can not be ruled out that this accusation still referred to the activities of the archbishop Bertrand.

${ }^{141}$ Toomaspoeg, Templari, 143 no. 6 I.

${ }_{142}$ Ibid., 56.

${ }^{143}$ Bullarium Ordinis Militiae de Alcantara, ed. Ortega y Cotes, Fernandez de Brizuela, and Ortega Zuñiga y Aranda, I 9 I-I 94.

${ }_{144}$ Tabulae, ed. Strehlke, I 80-I 82 no. I 95. 
and the resort to a "third party". ${ }^{145}$ The other regions of the West and East are not documented by such a complete series, but almost everywhere - with the exception of some territories like the Kingdom of Sicily - the military orders and local bishops signed mutual agreements, many of which still survive. ${ }^{146}$ In many cases, several agreements were signed in the same diocese. Just to take an example, in the diocese of Jaén the Order of Calatrava and the bishops concluded six agreements between $\mathrm{I} 245$ and $1382,{ }^{147}$ the frequency of those contracts being explained by the fact that often their stipulations were not respected by either side. ${ }^{148}$

Those agreements - undoubtedly the best sources for a study of the relations between bishops and the military orders - were often intended as solutions to conflicts, but in other occasions they simply established the division of territories and incomes between the diocesan powers and the orders in the initial phase of their settlement. For example, in the diocese of Saragossa the bishop Bernard and the Templars agreed in July I 47 that the latter were to pay half of the tithes on labores cultivated by themselves and all the tithes due for other grounds, but that they could keep the incomes of the lands still to reclaim. ${ }^{\text {I9 }}$ Similar agreements were concluded between the Templars and the bishops of Lleida and Pamplona two years later. ${ }^{150}$ An interesting charter, dating of 1276 , handles the question of administration of the former Islamic territories, the bishop of Saragossa and the Order of Calatrava stipulating that the order was to expel the "Saracens" from the episcopal village of Calanda, Aragon (today in the province of Teruel), and to populate this and other three localities with Christians and build churches there, submitted to the bishop's authority. Calatrava promised also to pay the bishop one fourth of the tithes and a procuration. ${ }^{\text {sI }}$

Most of the agreements dealt with the issue of ecclesiastical taxes. In I 257 , in Acre, the Teutonic Order agreed with the bishop Florent on tithes and procuration, resulting in a document consisting of quite a long list ${ }^{152}$; in 1267 the master of Calatrava and the archbishop of Seville settled the question of tithes payed

\footnotetext{
145 Krämer, Dämonen, 34 I-600.

146 See the case of the Templars in the Latin East in Claverie: L'ordre, I $56-158$.

147 Menache, "La orden," 640-645.

${ }_{148}$ Among many cases of disrespect for the accords, see for example that of the bishop of Tarragona who, in I I 84-85, had forced the Hospitallers to pay tithes, against previous agreements between the episcopal see and the Hospital: Cartulaire générale de l'Ordre des Hospitaliers, I, ed. Delaville le Roulx, 459-460 no. 695.

149 Cartulaire général de l'Ordre du Temple, ed. Albon, 285-286 no. 360.

iso Ibid., 334 no. 545, 345-346 no. 557.

is 1 Bullarium Ordinis Militiae de Calatrava, ed. Ortega y Cotes, Alvarez de Baquedano, and Ortega Zuñiga y Aranda, I 38 -I 42.

I52 Tabulae, ed. Strehlke, 9I-94 no. I I 2.
} 
by Christians (one third went to the bishop) and Muslims and Jews (one tenth to the bishop), the fines paid by sacrilege (one half to the bishop), the procuration and cathedraticum. ${ }^{153}$ In many other cases, the funeral legacies and donations were also divided. ${ }^{154}$ Another important issue was the presentation of priests and chaplains and the bishops' jurisdiction on the churches of the military orders. In substance, the agreements treated all the sources of conflicts already mentioned above. Those documents were different from those signed not with bishops but with the local chapters, like that of 1220 between the Hospitallers and the Church of Besançon, ${ }^{155}$ which concentrated on the division of smaller fiscal and juridical incomes from single localities.

Before analysing the advantages and disadvantages of those agreements, it seems useful to take a concrete example, that of the Templars in Portugal. Being settled in Portuguese territory since i I 28, from I 59 the Templars were in a situation of conflict with local prelates, except for those in the southern part of the kingdom, where the order never established itself. It was only in the following century that the Templars felt the need to negotiate with the bishops and to determine the respective rights and territories. Consequently, agreements were signed from 1220 onwards with the archbishops and bishops of Braga ${ }^{156}$, Coimbra ${ }^{157}$, Guarda $^{158}$, Lamego ${ }^{159}$, Lisbon ${ }^{160}$, Porto ${ }^{161}$, and Viseu ${ }^{162}$. Those are very typical documents in the context of agreements between the Iberian orders and local bishops, establishing the fiscal and ecclesiastical rights of the bishop in single estates or churches of the order, all situated outside of the main Templar estates in the Lower Beira, within the diocesan territories. ${ }^{163}$

153 Bullarium Ordinis Militiae de Calatrava, ed. Ortega y Cotes, Alvarez de Baquedano, and Ortega Zuñiga y Aranda, I 26- I 28.

${ }_{154}$ For example between Alcántara and the bishop of Badajoz in I257, Bullarium Ordinis Militiae de Alcantara, ed. Ortega y Cotes, Fernandez de Brizuela, and Ortega Zuñiga y Aranda, 94-95.

iss Cartulaire générale de l'Ordre des Hospitaliers, II, ed. Delaville le Roulx, 266-267 no. I 669.

${ }_{156}$ February I 227, Lisbon, Arquivo Nacional da Torre do Tombo (henceforth as: ANTT), Gavetas 7 , maço I 2 , doc. I 3 .

1575 April I 291, ANTT, Gavetas 7, maço 7, doc 22.

${ }_{158} 30$ November I 220, ANTT, Leitura Nova, Livro I de Mestrados, f. 33 r-v; September I 242, ANTT, Ordem de Cristo, Documentos particulares, maço I, doc. 20 and other exemplars.

159 April I 252, ANTT, Gavetas 7, maço I 2, doc. I 2.

16027 April I 306, ANTT, Gavetas 7, maço 4, doc. 3.

${ }_{161} 25$ March I 244, ANTT, Gavetas 7, maço Io, doc. I 9.

16229 July I 230, ANTT, Gavetas 7, maço I 3, doc. 24.

${ }_{163}$ The actions of the Temple seem to have been successful: unlike other regions and dioceses, those agreements rarely had to be repeated and any conflicts persisting between the Templars of Portugal and the local bishops are documented. At the same time, the other military orders had not resolved their quarrels: so, in I 265, the Brethren of Alcántara had a conflict with the bishop 
For example, in 1250 the bishop of Guarda and the local Templars decided that the order should have a church in the city of Guarda and that the bishop should receive half of the tithes and also a quite substantial procuration in kind (bread and wine, pigs and chicken, butter, pepper, etc.) and wax every time he visited the church. The same division of incomes and rights was established for the church of Marmeleiro, about fourteen kilometers south-east of Guarda, while the Templar churches in Salvaterra do Extremo, on the border with Castile, paid the bishop one third of their tithes and a procuration in food and wax. In Segura, some thirteen kilometers southward, on the border, the Templars delivered one fourth of the tithes and the procuration. If the Templar Order acquired other churches in the diocese, it should cede their complete tithes to the bishop. In a number of localities, like Castelo Branco, Rodão, Idanha-a-Nova, Proença-a-Velha, Salvaterra, and Segura, the order had to pay the bishop an annual tax of fifteen maravedis, corresponding to one third of the legacies. Finally, the priests and chaplains of the Templar churches in the dioceses had to be presented before the bishop, who on his part promised not to issue interdicts on the order's houses. ${ }^{164}$

As this very typical agreement indicates, circumstances could vary according to location within the same diocese, ${ }^{165}$ following the degree of power and the economic interests of the bishops. Overall, the conditions were more prohibitive for the military orders in the residence cities of the bishops and in the centers of the dioceses and more favourable in the rural areas and in the fronteira with the Muslims or other Christian states, like Salvaterra and Segura in the diocese of Guarda. Now, if we compare the papal privileges of the military orders with the clauses of the agreements with bishops, it becomes evident - more in the West than in the Latin East ${ }^{166}$ - that the orders ceded not few of their rights, with a certain attitude of pragmatism. At the same time, these documents imply an official recognition of diocesan power from the orders.

However, the same pragmatism can be observed also on the other side. The bishops rarely descended into conflict with the orders for reasons other than the direct interests of their dioceses. They acted in the same vein as their predecessors, defending the prestige, the territory, and the incomes of their bishopric, often le-

of Guarda on the issue of tithes: Bullarium Ordinis Militiae de Alcantara, ed. Ortega y Cotes, Fernandez de Brizuela, and Ortega Zuñiga y Aranda, I I I - I I 2.

${ }_{164}$ April I 250, ANTT, Gavetas I 9, maço I 3, doc. 39.

165 This fact has been noted also by Thomas Krämer in Provence and South Germany, see: Krämer, Dämonen, i 7 .

${ }_{166}$ Claverie, L'ordre, I 58. 
galising the usurpations committed by the military orders. ${ }^{167}$ Criticism from prelates like Jacques de Vitry or William of Tyre ${ }^{168}$ can be explained by the difficult coexistence of the diocesan structures and the houses of the military orders in certain areas.

\section{CONCLUSION}

The exact nature of the relationship between the military orders and the secular clergy has been evaluated by scholars in different ways. Obviously, judgment depends on the chronological and geographical context on which the historian works. Thus there is an opinion that the diocesan authorities "hated" the exempted congregations of the military orders, ${ }^{169}$ based mostly on the documentation of the Latin East, and another opinion, based mostly on the cases from Southern France, stipulating that "In spite of structural tensions [...] there were cordial relations between the military orders and a clergy of which they were part." ${ }^{170}$ More detailed is the conclusion of Derek Lomax on the Iberian case: there was a period in which both the bishops and the orders rushed to define their respective competences, followed by a long time when distances were maintained and by conflicts in which the dioceses played the weaker part. ${ }^{171}$

Taking in account also the observations of Helen Nicholson on criticism of the military orders, ${ }^{72}$ there is no doubt that the circumstances are widely diverse. Nevertheless, some elements are common to every region and era. First of all, in the post-Reform period the bishoprics and the military orders can be considered as two distinct, concurrent but essential institutions of the Latin East and West. It is rare, for before the fourteenth and the fifteenth centuries, to see priests of the military orders consecrated as bishops, with the remarkable exception of the territories of the Teutonic Order. The case of the Teutonic Brethren in the dioces-

\footnotetext{
${ }_{167}$ To give a single example among many, in I 23 I the Brethren of Santiago were building churches in the archdiocese of Toledo in places which were not novalia, but belonged to the archbishop's jurisdiction: Bullarium equestris, ed. Aguado de Córdova, Alemán y Rosales, and López Agurleta, 94.

${ }^{168}$ Helen J. Nicholson, Templars, Hospitallers and Teutonic Knights. Images of the Military Orders, II 28-I29I (Leicester-London-New York: Leicester University Press, I 993), 35-48.

${ }_{169}$ Claverie, L'ordre, I 44.

${ }_{170}$ Damien Carraz, Clergé, in Prier et combattre. Dictionnaire européen des ordres militaires au Moyen Age, ed. Nicole Bériou and Philippe Josserand (Paris: Fayard, 2009), 238-239, here 239.

${ }^{171}$ Derek Lomax, "La Orden de Santiago y el obispado de Cuenca en la Edad Media," Anuario de Estudios Medievales I 2 ( 1982): 303-3 I0; Menache, "La orden," 43 footnote 39.

${ }_{172}$ Nicholson, Templars, 55-56.
} 
es of Prussia and some of Livonia does not fall within the framework of my study and concerns the topic of the territorialisation of the military orders. Their example was not followed by the other orders: for example, the bishops of Rhodes were not systematically members of the Hospital. There are relatively few cases of bishops from the military orders before the fifteenth century, like the often-mentioned Hospitaller and Templar superiors of Valania (Balanea) in Syria, Tarsus and Nazareth, mostly at a time when those dioceses were already under Muslim control. ${ }^{173}$

Two examples illustrate these considerations. In May i i 97, Pope Celestine III authorised the new bishop of Valania, who had become member of the Hospitaller Order, not to wear the Hospital's cross on his clothes and not to swear an oath to the order for the possession of the castle of Margat. ${ }^{174}$ That was certainly a drawback on the order's project of "taking over" the diocese, in that it established at least a symbolic distance between the Hospital and the bishop's see. In I 226 the chapter of the very small diocese of Lavello in the Kingdom of Sicily elected as new bishop a member of the Order of Temple, Richard. ${ }^{175}$ The Templars, as the Hospitallers and the Teutonic Knights, were popular in this specific region (today Basilicata and Apulia) which contained many of their houses and produced wheat and other supplies for the Holy Land. They were esteemed for their spirituality ${ }^{176}$ as well as for their skills as administrators. The papal curia of Honorius III, even if noting the chosen bishop's excellent reputation, did not accept the election, justifying the refusal with the fact that the procedure was not "customary" (consuetum), but leaving the door open for the consecration by ordering an enquiry on this issue. So, unlike the priests of all other male religious congregations, those of the military orders were, for the pope, not "customary" to become bishops.

The situation evolved in later times, with a series of Hospitallers being nominated bishops, but the prelates and the brethren of the military orders continued to represent two very distinct institutions. As we have seen, the relationship between the diocesan clergy and the military orders could be conflictive, pacific, or

173 Carraz, Clergé, 238, Claverie, L'ordre, I69-1 70.

${ }^{174}$ Cartulaire générale de l'Ordre des Hospitaliers, I, ed. Delaville le Roulx, 63 I-632 no. 999; Jonathan Riley-Smith, Knights of St. John in Jerusalem and Cyprus, c. Io5o-1310 (London: Macmillan, I967), 4I 2.

175 Kamp, Kirche, I.2: 638; Hubert Houben, "Templari e Teutonici nel Mezzogiorno normanno-svevo," in Il Mezzogiorno normanno-svevo e le Crociate. Atti delle quattordicesime giornate normanno-sveve. Bari, 17-20 ottobre 200o, ed. Giosuè Musca (Bari: Dedalo, 2002), 25 I-288, here 268.

${ }^{176}$ Houben, "Zur Geschichte," 6 I ; Kristjan Toomaspoeg, "La spiritualité des ordres religieux-militaires du Moyen Âge: l'état de la recherche," in Cister e as Ordens Militares na Idade Média - Guerra, Igreja e Vida Religiosa, ed. José Albuquerque Carreiras, Carlos de Ayala Martínez (Tomar: Associação portuguesa de Cister, 20 I 5), 23-45, here 23-24. 
friendly, but in every case it ended with a certain balance of powers being achieved. This is valid for regions as different as the Kingdom of Sicily and the Kingdom of Portugal.

In south Italy, the orders acted on the same level as the bishops, and in the case of the clash in Messina in I 344, the Hospitaller house was one of three centers of power in the city, besides the bishop's palace and the royal castle. In many regions of the Iberian Peninsula, the economic and demographic configuration of the territory was in part due to the agreements between the bishops and the military orders. An old esoteric theory pretends that Portugal was formed by the Templars. ${ }^{177}$ That was certainly not the case, but the Portuguese territory was surely influenced by the common action of military orders and bishops.

The military orders acted as competitors, but sometimes also as allies and partners of the bishops, and the two institutions can be considered among the pillars of the Church of the late middle ages.

\section{PRIMARY SOURCES:}

Lisbon. Arquivo Nacional da Torre do Tombo, Gavetas 7, maço 4, doc. 3; maço 7, doc 22; maço IO, doc. I9; maço I2, doc. I 2 and I3; maço I3, doc. 24 and 39.

Lisbon. Arquivo Nacional da Torre do Tombo, Leitura Nova, Livro I de Mestrados.

Lisbon. Arquivo Nacional da Torre do Tombo, Ordem de Cristo, Documentos particulares, maço I, doc. 20.

Palermo, Biblioteca Comunale, Qq H I 2.

Toledo, Archivo Ducal de Medinaceli, Adm., Archivio Histórico, legajo 98-I.

Bulário Português. Inocêncio III (IIg8-I2I6). Edited by Avelino de Jesus da Costa and Maria Alegria F. Marques. Coimbra: Instituto nacional de investigação científica, 1989.

Bullarium equestris ordinis Sancti Iacobi de Spatha per annorum seriem nonnullis donationum et aliis interiectis scripturis congestum. Edited by Antonio Francisco Aguado de Córdova, Alfonso Antonio Alemán y Rosales, and José López Agurleta. Madrid: Sumptibus eiusdem ordinis. Ex typographia Ioannis de Ariztia, 17 I9.

Bullarium Ordinis Militiae de Alcantara olim S. Juliani del Pereiro per annorum seriem nonnullis donationum, concordiarum et aliis interjectis scripturis congestum. Edited by Ignacio José de Ortega y Cotes, José Fernandez de Brizuela, and Pedro Ortega Zuñiga y Aranda. Madrid: Ex typographia Antonij Marin. Sumptibus ejusdem ordinis, 1759 .

177 António Telmo, História Secreta de Portugal (Lisbon: Zéfiro, 1977), 59. 
Bullarium Ordinis Militiae de Calatrava per annorum seriem nonnullis donationum, concordiarum et aliis interjectis scripturis congestum. Edited by Ignácio José de Ortega y Cotes, Juan Francisco Alvarez de Baquedano, and Pedro de Ortega Zuñiga y Aranda. Madrid: Ioannis de Ariztia, 176 I.

Cartulaire général de l'Ordre du Temple i I g?-I Iso: recueil des Chartes et des Bulles relatives à l'Ordre du Temple formépar le Marquis d'Albon. Edited by Guigues Alexis Marie Joseph André d'Albon. Paris: Honoré Champion, i 9 I 3.

Cartulaire générale de l'Ordre des Hospitaliers de S. Jean de Jérusale. Vol. I-II. Edited by Joseph Marie Antoine Delaville le Roulx. Paris: Ernest Leroux, I 894-I 904.

Codice diplomatico barese. Vol. 9.I. I documenti storici di Corato (I046-I327). Edited by Giovanni Beltrani. Codice Diplomatico Barese IX/ I. Bari: Società Storia Patria Bari, 1923.

Cunha, Rodrigo. Da. Primeira parte da historia ecclesiastica dos arcebispos de Braga e dos Santos e Varoes illustres. Braga: Manoel Cardozo, I 634.

Decimae. Il sostegno economico dei sovrani alla Chiesa del Mezzogiorno nel XIII secolo. Dai lasciti di Eduard Sthamer e Norbert Kamp. Edited by Kristjan Toomaspoeg. Rome: Viella, 2009.

Gams, Pius Bonifacius. Series Episcoporum Ecclesiae Catholicae. Vol. I. Leipzig: Manz, I 873 .

Italia Pontificia, IX, Samnium-Apulia-Lucania. Edited by Wather Holtzmann. Berlin: ZVAB, i 962.

Linehan, Peter. Portugalia Pontificia: Materials for the history of Portugal and the papacy I198-1417. Vol. I. Lisbon: Fundação Calouste Gulbenkian, 2013.

Liv-, Esth-und Curländisches Urkundenbuch nebst Regesten. Vol. I. I. Edited by Friedrich Georg von Bunge. Reval (Tallinn): Kluge und Ströhm, I 853.

Mansi, Giovanni Domenico. Sacrorum Conciliorum nova et amplissima collectio. Vol. XXII. Venice: Apud Antonium Zatta, 1778 (repr. Graz: Akademische Druck u. Verlagsanstalt, I96I).

Monumenta Henricina. Vol. I. Edited by Manuel Lopes de Almeida, Idalino Ferreira da Costa Brochado, and Antonio Joaquim Dias Dinis. Coimbra: UC Biblioteca Geral I, I 960 .

Papsturkunden in Portugal. Edited by Carl Erdmann. Berlin: Weidmannsche Buchhandlung, 1927.

Patrologiae Cursus Completus: Series Latina. Vol. 2 I 4. Innocentius III Pontifex Romanus. Edited by Jacques Paul Migne. Paris: apud J.P. Migne, I 855.

Régistres de Grégoire IX. Edited by Lucien Auvray. Vol. I. Paris: Albert Fontemoing, i 896. Petracca, Luciana. Giovanniti e Templari in Sicilia. Vol. II, Il ms. Qq HI2 della Biblioteca Comunale di Palermo. Galatina: Congedo, 2006 (Source edition 299-302).

Tabulae Ordinis Theutonici. Ex tabularii regii Berolinensis codice potissimum. Edited by Ernst Strehlke. Berlin: Weidmann, I 869.

Die Urkunden des Deutschordens-Zentralarchivs in Wien. Regesten. Edited by Udo Arnold. Marburg: N. G. Elwert, 2006-2009. 


\section{SECONDARY SOURCES:}

Bellomo, Elena. The Templar Order in North-West Italy (II42-C.1330). Leiden-Boston: Brill, 2008.

Benninghoven, Friedrich. Der Orden der Schwertbrüder. Fratres Milicie Christi de Livonia. Cologne-Graz: Böhlau, I965.

Carraz, Damien, “Clergé.” In Prier et combattre. Dictionnaire européen des ordres militaires au Moyen Age, edited by Nicole Bériou and Philippe Josserand, 238-239. Paris: Fayard, 2009.

Carraz, Damien. L'Ordre du Temple dans la basse vallée du Rhône (II24-I3I2). Ordres militaires, croisades et sociétés méridionales. Lyon: Presses Universitaires de Lyon, 2005.

Cerrini, Simonetta. "Une expérience neuve au sein de la spiritualité médiévale: l'ordre du Temple ( I I 20-I 3 I 4). Étude et édition des règles latine et française.” PhD Dissertation, Université de Paris IV-Sorbonne, I 997.

Claverie, Pierre-Vincent. Lordre du Temple en Terre Sainte et à Chypre au XIII' siècle. Nicosia: Centre de Recherche Scientifique, 2005.

Corral Val, Luis. "La Orden de Alcántara: organización institucional y vida religosa en la edad media. " PhD Dissertation, Universidad Complutense Madrid, I 998.

Ehlers, Axel. "The use of indulgences by the Teutonic Order in the Middle Ages." In The Military Orders. Vol. 3, History and Heritage, edited by Victor Mallia Milanes, I 39- I 45. Aldershot: Routledge, 2008.

Ehlers, Axel. Die Ablasspraxis des Deutschen Ordens im Mittelalter. Marburg: N. G. Elwert, 2007.

Filotico, Francesco. Le origini del Baliato di Bolzano nel quadro del primo sviluppo dell'Ordine Teutonico (I200-I270). Galatina: Congedo, 2015.

Fonseca, Cosimo Damiano. "Le istituzioni ecclesiastiche e la conquista normanna. Gli episcopati e le cattedrali." In I caratteri originari della conquista normanna. Diversità e identità nel Mezzogiorno (I030-II30). Atti delle sedicesime giornate normanno-sveve, Bari, 5-8 ottobre 2004, edited by Raffaele Licinio and Francesco Violante, 335-348. Bari: Edizioni Dedalo, 2006.

Forey, Alan J. “The Siege of Lisbon and the Second Crusade." Portuguese studies 20 (2004): $\mathrm{I}-\mathrm{I} 3$.

García-Guijarro Ramos, Luis. "Exemption in the Temple, the Hospital and the Teutonic Order. Shortcomings of the Institutional Approach." In The Military Orders. Vol. 2, Welfare and Warfare, edited by Helen J. Nicholson, 289-293. Aldershot: Routledge, I 998.

Houben, Hubert. "Auf dem Weg ins Heilige Land. Deutsche Pilger, Kreuzfahrer und Ordensritter in Italien." In Die Kreuzzugsbewegung im römisch-deutschen Reich (II.-I3-Jahrhundert), edited by Nikolas Jaspert and Stefan Tebruck, I 03 - I I 8. Ostfildern: Jan Thorbecke, 2016.

Houben, Hubert. "I vescovi e l'imperatore." In Federico II nel Regno di Sicilia. Realtà locali e aspirazioni universali. Atti del convegno internazionale di studi (Barletta, Ig-2o ottobre 2007), edited by Hubert Houben, I73- i 88. Bari: Adda Editore, 2008. 
Houben, Hubert. “Templari e Teutonici nel Mezzogiorno normanno-svevo.” In Il Mezzogiorno normanno-svevo ele Crociate. Atti delle quattordicesime giornate normanno-sveve. Bari, I7-20 ottobre 2000, edited by Giosuè Musca, 25 I-288. Bari: Dedalo, 2002.

Houben, Hubert. "Zur Geschichte der Deutschordensballei Apulien. Abschriften und Regesten verlorener Urkunden aus Neapel in Graz und Wien." Mitteilungen des Instituts für Österreichische Geschichtsforschung 107, no. I-2 (1 999): 50- I I 0.

Hunyadi, Zsolt. The Hospitallers in the medieval Kingdom of Hungary, c. II 50-1387. Budapest: Central European University Press, 20 io.

Iorio, Raffaele "Uomini e sedi a Barletta di Ospedalieri e Templari come soggetti di organizzazione storica." In Barletta crocevia degli Ordini religioso-cavallereschi medioevali. Seminario di Studio, Barletta I 6 giugno I9g6, edited by Renato Paternò di Montecupo, 7 I-I I 9. Taranto: Centro Studi Melitensi, I 997.

Josserand, Philippe. Église et pouvoir dans la Péninsule Ibérique. Les ordres militaires dans le royaume de Castille (I252-I369). Madrid: Casa de Velázquez, 2004.

Norbert Kamp, Kirche und Monarchie im Staufischen Königreich Sizilien. Vol. I. Prosopographische Grundlegung: Bistümer und Bischöfe des Königreichs IIg4 - I266. Part 2. Apulien und Kalabrien. München: Wilhelm Fink Verlag, 975.

Norbert Kamp, Kirche und Monarchie im Staufischen Königreich Sizilien. Vol. I. Prosopographische Grundlegung: Bistümer und Bischöfe des Königreichs IIg4 - I266. Part 3. Sizilien. München: Wilhelm Fink Verlag, i 975.

Krämer, Thomas. Dämonen, Prälaten und gottlose Menschen. Konflikte und ibre Beilegung im Umfeld der geistlichen Ritterorden (Berlin-Münster: LIT, 20 I 6).

Lomax, Derek. "La Orden de Santiago y el obispado de Cuenca en la Edad Media." Anuario de Estudios Medievales I 2 ( 1982): 303-3 I 0.

Lomax, Derek. La Orden de Santiago. Escuela de estudios medievales. Estudios 38. Madrid: Consejo Superior de Investigaciones Científicas, Escuela de Estudios Medievales, I 965 .

Lomax, Derek. The Order of Santiago, II70-I275. Oxford: The Confraternity of Saint James, I 960.

Luttrell, Anthony. “Introduzione generale." In Linchiesta pontificia del 1373 sugli Ospedalieri di San Giovanni di Gerusalemme nel Mezzogiorno d'Italia, edited by Mariarosaria Salerno and Kristjan Toomaspoeg, 7-30. Bari: Adda Editore, 2008.

Marullo di Condojanni, Carlo. La Sicilia ed il Sovrano Ordine Militare di Malta. Messina: Grafiche "La Sicilia", I 953.

Menache, Sophia. "La orden de Calatrava y el clero andaluz (siglos XIII-XV)." In Estudios en memoria del profesor don Claudio Sánchez-Albornoz. Vol. I, edited by Miguel Angel Ladero Quesada, 633-653. En la España Medieval 5. Madrid: Universidad Complutense, i 986.

Militzer, Klaus. "Porte-Glaive, ordre des." In Prier et combattre. Dictionnaire européen des ordres militaires au Moyen Age, edited by Nicole Bériou and Philippe Josserand, 729-730. Paris: Fayard, 2009. 
Montaña Conchiña, Juan Luis de la. "Obispados y órdenes militares. Problemas jurisdiccionales en la Transierra extremeña del siglo XIII.” Alcantara. Revista del Seminario de Estudios Cacereños 34, no. I (1995): 29-48.

Nicholson, Helen J. Templars, Hospitallers and Teutonic Knights. Images of the Military Orders, II28-I29I. Leicester-London-New York: Leicester University Press, I 993.

O'Malley, Gregory. The Knights Hospitaller of the English Langue, I460-I565. Oxford: Oxford University Press, 2005.

Petracca, Luciana. Giovanniti e Templari in Sicilia. Vol. II. II ms. Qq HI2 della Biblioteca Comunale di Palermo. Galatina: Congedo, 2006.

Phillips, Jonathan. "Ideas of Crusade and Holy War in De expugnatione Lyxbonensi (The Conquest of Lisbon)." In Holy Land, Holy Lands, and Christian History, edited by Robert N. Swanson, I 23-I 4I. Woodbridge: Boydell \& Brewer, 2000.

Riley-Smith, Jonathan. Knights of St. John in Jerusalem and Cyprus, c. Ioso-1310. London: Macmillan, I 967.

Riley-Smith, Jonathan. The Knights Hospitaller in the Levant, c. 1070-1309. Basingstoke etc: Palgrave Macmillan, 20 I 2.

Salerno, Mariarosa. "The military orders and the local population in Italy: connections and conflicts." In The Military Orders. Vol. 6.2, Culture and Conflict in Western and Northern Europe, edited by Jochen Schenk and Mike Carr, I 72-I 82. London-New York: Routledge, 20 I 7.

Salerno, Mariarosa. Gli ospedalieri di San Giovanni di Gerusalemme nel Mezzogiorno d'Italia (secc. XII-XV). Taranto: Centro Studi Melitensi, $200 \mathrm{I}$.

Salerno, Mariarosaria and Kristjan Toomaspoeg. L'inchiesta pontificia del 1373 sugli Ospedalieri di San Giovanni di Gerusalemme nel Mezzogiorno d'Italia. Bari: Adda Editore, 2008.

Santoro, Daniela. "L'arcivescovo e l'Ospedale. Raimondo de Puyolis contro i Gerosolimitani di Messina (1 344)." In Istituzioni ecclesiastiche e potere regio nel Mediterraneo medievale. Scritti per Salvatore Fodale, edited by Patrizia Sardina, Daniela Santoro and Maria Antonietta Russo, 75-90. Palermo: Associazione no profit Mediterranea, 2016.

Schenk, Jochen. "Aspects and Problems of the Templars' Religious Presence in Medieval Europe from the twelfth to the early fourteenth Century." Traditio 7I (2016): 273-303.

Schenk, Jochen. Templar families: landowning families and the Order of the Temple in France, c. II20-1307. Cambridge-New York: Cambridge University Press, 2012.

Telmo, António. História Secreta de Portugal. Lisbon: Zéfiro, I 977.

Toomaspoeg, Kristjan. La contabilità delle Case dell'Ordine Teutonico in Puglia e in Sicilia nel Quattrocento. Galatina: Congedo, 2005.

Toomaspoeg, Kristjan. " 'Confratres, procuratores, negociorum gestores et factores eorum...' Storia dei familiares dei Cavalieri Teutonici in Sicilia (I 197-1 492)." Sacra Militia. Rivista di storia degli ordini militari I (2000): I 5 I - I65.

Toomaspoeg, Kristjan. "Gli insediamenti templari, giovanniti e teutonici nell'economia della Capitanata medievale." In Federico II e i cavalieri teutonici in Capitanata. Recenti 
ricerche storiche e archeologiche. Atti del Convegno internazionale (Foggia-Lucera-Pietra Montecorvino, Io-I3 giugno 2009), edited by Pasquale Favia, Hubert Houben and Kristjan Toomaspoeg, i 83-2 I 4. Galatina: Congedo, 20 I 2.

Toomaspoeg, Kristjan. "I Templari nel Mezzogiorno e nelle isole." In I Templari. Grandezza e caduta della 'Militia Christi', edited by Giancarlo Andenna, Cosimo Damiano Fonseca, and Elisabetta Filippini, 75-83. Milan: Vita e Pensiero, 20 I6.

Toomaspoeg, Kristjan. “La fondazione della provincia di 'Lombardia' dell'Ordine dei Cavalieri Teutonici (secoli XIII-XIV).” Sacra Militia. Rivista di storia degli ordini militari 3 (2003): I I I-I 59 .

Toomaspoeg, Kristjan. "La spiritualité des ordres religieux-militaires du Moyen Âge: l'état de la recherche." In Cister e as Ordens Militares na Idade Média - Guerra, Igreja e Vida Religiosa, edited by José Albuquerque Carreiras, Carlos de Ayala Martínez, 23-45. Tomar: Associação portuguesa de Cister, 20 I 5.

Toomaspoeg, Kristjan. “The Marquis of Albon, Carl Erdmann and the Templar Sources in Portugal." In The Templars and their Sources, edited by Karl Borchardt, Karoline Döring, Philippe Josserand, and Helen J. Nicholson, I o6- I 22. New York: Routledge, 20 I 7.

Toomaspoeg, Kristjan. „Le grenier des Templiers. Les possessions et l'économie de l'Ordre dans la Capitanate et en Sicile." In L'économie templière en Occident. Patrimoines, commerce, finances. Actes du colloque international (Troyes-Abbaye de Clairvaux, 24-26 octobre 2012), edited by Arnaud Baudin, Ghislain Brunel and Nicolas Dohrmann, 93-I I 3. Langres: D. Guéniot-Conseil général de l’Aube, 20 I 3.

Toomaspoeg, Kristjan. "L'Ordine Teutonico nel Mediterraneo: bilancio e prospettive di ricerca - Der Deutsche Orden im Mittelmeerraum: Bilanz und Forschungsperspektiven." In L'Ordine Teutonico tra Mediterraneo e Baltico: incontri e scontri tra religioni, popoli e culture - Der Deutsche Orden zwischen Mittelmeerraum und Baltikum. Begegnungen und Konfrontationen zwischen Religionen, Völkern und Kulturen, edited by Hubert Houben and Kristjan Toomaspoeg, 35-63. Galatina: Congedo, 2008.

Toomaspoeg, Kristjan. Les Teutoniques en Sicile (II97-1492). Rome: École française de Rome, 2003.

Toomaspoeg, Kristjan. Templari e Ospitalieri nella Sicilia Medievale. Taranto-Bari: Centro Studi Melitensi, 2003. 